$$
\text { Universidade de São Paulo }
$$

Faculdade de Medicina de Ribeirão Preto

Departamento de Medicina Social

Mestrado Saúde na Comunidade

MURILO CÉSAR DO NASCIMENTO

Geoepidemiologia da Dengue no Município de

Alfenas, MG

Ribeirão Preto-SP 

MURILO CÉSAR DO NASCIMENTO

\title{
Geoepidemiologia da Dengue no Município de Alfenas, MG
}

\author{
Dissertação apresentada ao Programa de Pós- \\ Graduação do Departamento de Medicina Social da \\ Faculdade de Medicina de Ribeirão Preto da \\ Universidade de São Paulo, para a obtenção do título \\ de Mestre. \\ Área de Concentração: Saúde na Comunidade \\ Orientador: Prof. Dr. Antônio Luiz Rodrigues Júnior
}

Ribeirão Preto-SP 
Autorizo a reprodução e divulgação total ou parcial deste trabalho, por qualquer meio convencional ou eletrônico, para fins de estudo e pesquisa, desde que citada a fonte.

FICHA CATALOGRÁFICA

Nascimento, Murilo César do.

Geoepidemiologia da Dengue no Município de Alfenas, MG. 2011. 70 p.: il. ; $30 \mathrm{~cm}$

Dissertação (Mestrado) apresentada à Faculdade de Medicina de Ribeirão Preto/USP - Área de concentração: Saúde na Comunidade.

Orientador: Rodrigues Júnior, Antônio Luiz

1. dengue. 2. epidemiologia descritiva. 3. distribuição espacial da população. 4. programa saúde da família. 5. classe social. II. Título.

CDD: 616.91852 


\section{FOLHA DE APROVAÇÃO}

Murilo César do Nascimento

Geoepidemiologia da Dengue no Município de Alfenas, MG

Dissertação apresentada ao Programa de PósGraduação do Departamento de Medicina Social da Faculdade de Medicina de Ribeirão Preto da Universidade de São Paulo, para a obtenção do título de Mestre.

Aprovado em:

\section{Banca Examinadora}

Prof. Dr. Antônio Luiz Rodrigues Júnior

Assinatura:

Instituição: Faculdade de Medicina de Ribeirão Preto-USP

Prof. Dr. Amaury Lélis Dal Fabbro

Assinatura:

Instituição: Faculdade de Medicina de Ribeirão Preto-USP

Prof. Dr. Denismar Alves Nogueira

Assinatura:

Instituição: Universidade Federal de Alfenas, Unifal-MG 

À querida

Marina Abrão Torres 



\section{AGRADECIMENTOS}

A Deus.

Aos familiares, em especial, Murilo Sérgio do Nascimento, Elma Aparecida Ribeiro do Nascimento e

Fernanda Ribeiro do Nascimento.

Aos amigos, de forma particular, Maria Inêz Barbosa Braga Bérgamo, Maria Betânia Tinti de Andrade, Valério Landim de Almeida e Júlio César Barbosa.

Ao professor e orientador, Prof. Dr. Antônio Luiz Rodrigues Júnior. Aos professores e colegas, principalmente, Prof. Dr. Amaury Lelis Dal Fabbro, Prof. Dr. Denismar Alves Nogueira, Prof. Dr. Jair Lício Ferreira Santos e Eloisa Maria Steluti.

Aos pesquisadores, Prof. Dr. Christovam Barcellos e Prof. Dr. Reinaldo Souza-Santos.

Aos parceiros e colaboradores, Rodolfo Chaib, Dênis de Oliveira Rodrigues e Ludmila Barbosa Bandeira Rodrigues. 

"Não sei o que possa parecer aos olhos do mundo, mas aos meus pareço apenas ter sido como um menino brincando à beira-mar, divertindo-me com o fato de encontrar de vez em quando um seixo mais liso ou uma concha mais bonita que o normal, enquanto o grande oceano da verdade permanece completamente por descobrir à minha frente". 



\section{RESUMO}

Nascimento, Murilo César do. Geoepidemiologia da Dengue no Município de Alfenas, MG. 2011. 69 p. Dissertação (Mestrado) - Faculdade de Medicina de Ribeirão Preto, Universidade de São Paulo, Ribeirão Preto, 2011.

A incidência de dengue no Município de Alfenas-MG foi estudada, entre os anos de 2001 e 2010, por meio de estudo transversal, utilizando variáveis referentes à pessoa, tempo e lugar dos casos autóctones de dengue, cujas informações foram obtidas no Sinan; as variáveis socioeconômicas foram disponibilizadas pelo IBGE e dados cartográficos foram cedidos pela Prefeitura Municipal. $\mathrm{Na}$ análise descritiva utilizou-se a análise multivariada e a análise espacial para descrever o perfil epidemiológico dos casos e a distribuição espacial das residências segundo bairros urbanos, áreas do Programa Saúde da Família e setores censitários de agrupamentos socioeconômicos distintos. Observou-se uma heterogeneidade da distribuição espacial dos casos e a ausência de padrão das densidades espaciais. Os principais aglomerados de casos foram identificados em áreas descobertas pela Estratégia Saúde da Família, apesar de as distribuições de frequência terem sido semelhantes nos extratos socioeconômicos; tais características podem estar associadas à dinâmica da circulação viral na localidade, considerando-se a mobilidade interna e o fluxo humano, além da atuação gradativa das Equipes de Saúde da Família no Município.

Palavras-chave: Dengue. Epidemiologia Descritiva. Distribuição Espacial da População. Programa Saúde da Família. Classe Social. 


\section{ABSTRACT}

Nascimento, Murilo César do. Geopidemiology of dengue in the Alfenas city, Minas Gerais state - Brazil. 2011. 69 p. Dissertation (Masters Degree) - Medical School at Ribeirão Preto, University of São Paulo, Ribeirão Preto, 2011.

The incidence of dengue in Alfenas-MG was studied between the years 2001 and 2010, through cross-sectional study, using variables related to the person, time and place of autochthonous cases of dengue, whose information was obtained in the Sinan, the socioeconomic variables were provided by IBGE and map data were provided by City Hall. In the descriptive analysis we used multivariate analysis and spatial analysis to describe the epidemiological profile of cases and spatial distribution of second homes urban neighborhoods, areas of the Family Health Program and census tracts of different socioeconomic groups. There was a heterogeneity of the spatial distribution of cases and the absence of spatial pattern of densities. The main clusters of cases were identified in areas uncovered by the Family Health Strategy, despite the frequency distributions were similar across socioeconomic strata, such features may be associated with the dynamics of viral circulation in the locality, considering the internal mobility and the human stream, and graded the performance of the Family Health Teams in the city.

Keywords: Dengue. Descriptive Epidemiology. Residence Characteristics. Family Health Program. Social Class. 


\section{LISTA DE TABELAS}

TABELA 1 - Distribuição das notificações de dengue e classificação final das investigações no município de Alfenas, de 2001 a 2010 36

TABELA 2 - Caracterização dos casos confirmados de dengue no Município de Alfenas-MG, entre 2001 e 2010, segundo faixa etária, sexo, raça e escolaridade

TABELA 3 - Valores médios dos parâmetros socioeconômicos utilizados para classificar os setores censitários e clusters quanto ao nível socioeconômico

TABELA 4 - Caracterização dos extratos socioeconômicos quanto à distribuição da dengue pelos domicílios/setores

TABELA 5 - Caracterização dos setores censitários segundo nível socioeconômico, número de domicílios e ocorrência de dengue 66 


\section{LISTA DE FIGURAS}

FIGURA 1 - Coeficientes de incidência de dengue em Alfenas-MG, segundo meses, entre 2001 e 2010

FIGURA 2 - Mapa de pontos referentes às residências em que ocorreram casos autóctones de dengue clássico na área urbana de AlfenasMG, de 2001 a 2010

FIGURA 3 - Mapa de pontos e da densidade de residências com casos confirmados de dengue, entre 2001 e 2010, em Alfenas-MG

FIGURA 4 - Densidade de casos de dengue e áreas cobertas pela Estratégia Saúde da Família em Alfenas-MG, entre 2001 e 2010

FIGURA 5 - Dendograma para Análise de Cluster, elaborado pelo método do Agrupamento Hierárquico de Ward

FIGURA 6 - Concentração de casos pelos setores censitários agrupados por níveis socioeconômicos 


\section{LISTA DE SIGLAS E ABREVIATURAS}

ACS Agente Comunitário de Saúde.

APS Atenção Primária à Saúde.

AVE Avenida.

CCD Coordenadoria de Controle de Doenças.

DATASUS Departamento de Informática do Sistema Único de Saúde.

DC Dengue clássico.

DENV Sorotipo da dengue.

ESF Estratégia Saúde da Família ou Equipe de Saúde da Família.

FHD Febre hemorrágica da dengue.

n Número de casos.

$\% \quad$ Porcentagem.

$\%$ acum. Porcentagem acumulada.

IBGE Instituto Brasileiro de Geografia e Estatística.

PSF Programa Saúde da Família.

SCD Síndrome do choque da dengue.

SIG Sistemas de Informações Geográficas.

Sinan Sistema de Informação de Agravos de Notificação.

STATA Data Analysis and Statistical Software.

SUCEN Superintendência de Controle de Endemias.

SUS Sistema Único de Saúde.

TRA Travessa.

WHO World Health Organization.

.mab Arquivo digital do tipo Microsoft Access Database. 


\section{SUMÁRIO}

1 INTRODUÇÃO__ 17

2 REFERENCIAL TEÓRICO __ 18

2.1 Dengue 18

2.2 Geoepidemiologia _ 19

2.3 Geoprocessamento e Sistemas de Informações Geográficas (SIG) _ 21

2.4 Lugar, espaço, território e saúde _ 22

2.5 Estratégia Saúde da Família e controle da Dengue _ 23

2.6 Saúde, dengue e o contexto socioeconômico___ 25

3 OBJETIVOS_ 27

3.1 Objetivo geral __ 27

3.2 Objetivos específicos 27

4 MATERIAL E MÉTODOS _ 28

4.1 Área de estudo _ 28

4.2 Delineamento do estudo __ 28

4.3 Coleta, tratamento e análise dos dados__ 28

4.4 Procedimentos éticos _ 35

5 RESULTADOS_ 36

6 DISCUSSÃO

7 CONSIDERAÇÕES FINAIS___ 58

REFERÊNCIAS _ 59

APÊNDICES 66

Apêndice I - TABELA 5. Caracterização dos setores censitários, segundo nível socioeconômico, número de domicílios e ocorrência de dengue _ 66

Apêndice II - Autorização para coleta de dados __ 68

Apêndice III - Aprovação pelo Comitê de Ética em Pesquisa ___ 69

Anexo I - Relatório de defesa da dissertação _ 70 


\section{INTRODUÇÃO}

A dengue é considerada uma das doenças reemergentes mais importantes da atualidade no Brasil e no Mundo. Em algumas cidades de clima tropical, por exemplo, o próprio entendimento da dengue como uma arbovirose de comportamento epidêmico não é mais unanimidade entre os pesquisadores. Alguns trabalhos já apresentam o termo "dengue endêmico" nas suas abordagens. De uma forma ou de outra, indiscutível tem sido o impacto desse problema no contexto econômico, social e de saúde da população.

Ao refletir sobre as estratégias de enfrentamento desse agravo nas últimas décadas, o que se percebe é que, de maneira intrigante, a dispersão do Aedes aegypti não tem sido controlada satisfatoriamente com os métodos tradicionais de combate às doenças transmitidas por vetores. Acredita-se que a reflexão sobre dois importantes conceitos da Geografia Médica possam auxiliar na compreensão da ocorrência da dengue e suas interfaces: o "foco natural da doença", de Evgeny Nikanorovich Pavlovsky e o "complexo patogênico", de Maximillien Sorre, referências dessa proposta de estudo.

Além disso, esse trabalho apresenta um teor prático porque propõe a utilização de algumas ferramentas da Geotecnologia em favor do setor saúde de Alfenas-MG, que foi considerado em 2002 um município prioritário para as ações do Programa Nacional de Controle da Dengue. A observação de diversas experiências exitosas em que a abordagem espacial auxiliou nas questões de saúde pública na escala intramunicipal foi que motivou o emprego de um Sistema de Informações Geográficas para o reconhecimento local da doença.

Trabalhos científicos recentes sobre o controle da dengue têm discutido, ainda, a importância dos fatores socioeconômicos na sua dinâmica de transmissão e destacado a necessidade da participação comunitária e da atenção primária à saúde nessa luta. Nesse contexto, o que se esperou é que esta pesquisa contribuísse com dados geoepidemiológicos sobre a incidência de dengue na área urbana de Alfenas$M G$, por meio da caracterização do perfil epidemiológico dos casos confirmados, da distribuição espacial das residências desses indivíduos e da descrição da relação entre os níveis socioeconômicos e a presença desse agravo na comunidade. 


\section{REFERENCIAL TEÓRICO}

\subsection{Dengue}

A dengue é uma doença epidêmica que constitui num dos agravos mais importantes da atualidade. Definida como doença infecciosa febril aguda, essa arbovirose é causada por um vírus do qual já foram identificados quatros sorotipos, 0 DENV-1, DENV-2, DENV-3 e o DENV-4. Sua forma de transmissão ao homem acontece pela picada do mosquito Aedes aegypti, principal vetor, podendo apresentar evolução benigna ou grave, dependendo da sua apresentação (BRASIL, 2008, 2007).

Infecção inaparente, dengue clássico (DC), febre hemorrágica da dengue (FHD) ou síndrome do choque da dengue (SCD) são, portanto, possíveis classificações dessa enfermidade. As formas graves, apesar de ocorrerem com menor frequência em relação às formas leves, não desmerecem atenção devido ao elevado potencial de letalidade e à complexidade dos cuidados que essas manifestações exigem (BRASIL, 2008, 2007; TORRES, 2005).

A ocorrência e a disseminação da dengue, especialmente nos países tropicais, se devem às próprias condições do meio ambiente que acabam por favorecer o desenvolvimento e a proliferação do vetor (WORLD HEALTH ORGANIZATION, 2009, 1997). No Brasil, as epidemias de dengue são registradas desde o século XIX. Em 1916 e no ano de 1923, houve relatos em São Paulo-SP e em Niterói-RJ, sem, entretanto, confirmação por exames laboratoriais. Já a primeira epidemia, documentada clínica e laboratorialmente, aconteceu na década de 1980, em Boa Vista-RR. A partir de então, o país tem sido acometido de forma continuada por epidemias que se intercalam e impactam expressivamente nos contextos econômico, social e de saúde pública das comunidades atingidas (BRASIL, 2009a, 2007).

No Estado de Minas Gerais, a primeira notificação ocorreu em 1987. Em 1998, Minas enfrentou sua primeira epidemia que atingiu toda a Unidade Federativa e, principalmente a região Metropolitana de Belo Horizonte. No ano de 1999, ocorreu diminuição no número de casos, porém esse quadro não se manteve, sendo observada nova tendência de aumento que culminou com o segundo pico epidêmico em 2002 (MINAS GERAIS, 2009). Nesse ano, o município de Alfenas, localizado no 
sul do Estado, foi considerado um município prioritário para as ações do Programa Nacional de Controle da Dengue (BRASIL, 2002a).

De acordo com a Secretaria de Estado de Saúde, houve redução de casos notificados de 2003 a 2006. Já o ano de 2006, em relação a 2005, apresentou nova tendência de aumento dos casos. Esse fato foi atribuído à introdução do sorotipo 3, à desmobilização político-administrativa de programas municipais, à descontinuidade das ações de controle vetorial e à desinformação da população sobre ações permanentes de prevenção. Tal situação levou à proposta de um plano de intensificação das ações que resultou na atualização do Plano Estadual de Controle da Dengue, elaborado em 2002. Entretanto, mesmo com a implementação das novas medidas, ocorreu discreto aumento no número de casos no ano de 2007 (MINAS GERAIS, 2009).

Pelo fato de a dengue estar contida na lista de doenças de notificação compulsória, o Ministério da Saúde orienta que todos os casos suspeitos ou confirmados sejam notificados ao Serviço de Vigilância Epidemiológica, por meio do Sistema de Informação de Agravos de Notificação - Sinan (BRASIL, 2008). Entretanto, cabe salientar que esse Sistema apresenta problemas de subnotificação, conforme expõem Souza, Vianna e Moraes (2007), por diversas razões, segundo Moraes e Duarte (2009), constituindo, assim, uma dificuldade que limita a representatividade e a abrangência dos dados.

\subsection{Geoepidemiologia}

Um trabalho realizado no ano de 2008, no qual se investigou a geoepidemiologia da co-morbidade de duas importantes doenças infecciosas num Estado da Região Sudeste Brasileira, o conceito de "Geoepidemiologia" foi apresentado como:

A disciplina que estuda a distribuição e os fatores determinantes das doenças, considerando os enfermos inseparáveis dos contextos do lugar onde vivem, mostrando a relevância do espaço geográfico no aparecimento, transmissão e distribuição das doenças (PIMENTA, 2008, p. 9).

Análises históricas sobre os primeiros conhecimentos em Geografia mostram que a associação entre esta e a Medicina não é recente, sendo identificado desde a 
Antiguidade o desenvolvimento de temas relacionando saúde, ambiente e espaço. No fim do século XIX, por exemplo, a aproximação entre a Geografia e a Epidemiologia resultou nos primeiros estudos em Geografia Médica. Entretanto, nessa época, a abordagem se restringia quase que exclusivamente à descrição detalhada da distribuição regional das doenças (VIEITES; FREITAS, 2007). Já no século XX, os conceitos de "foco natural de doença", do parasitologista russo Evgeny Nikanorovich Pavlovsky e de "complexo patogênico", do geógrafo francês Maximillien Sorre, marcaram uma nova fase nas relações entre a Geografia e a Epidemiologia, exatamente por permitirem uma interação teórica e metodológica (FERREIRA, 1991).

Pavlovsky (196-), apud Lemos e Lima (2002), recolheu elementos de abordagens ecológicas já utilizadas pela epidemiologia e expôs que um foco natural de doenças existe quando há clima, vegetação, solo e microclima favoráveis nos lugares onde vetores, doadores e receptores tornam-se abrigos de infecção. Ou seja, um foco natural de doenças está relacionado a uma paisagem geográfica específica. Assim, de acordo com Ferreira (1991), sua obra não é tão reconhecida por conter um caráter inovador, mas especialmente pela divulgação de um conjunto coerente de ideias aplicáveis a estudos de campo.

Já Sorre, tinha a preocupação teórica de propor uma base conceitual à geografia médica que pudesse fundamentar estudos de natureza interdisciplinar. Por isso, focou na importância da ação humana na formação e na dinâmica de complexo patogênico, que para ele se constitui a partir dos agentes causais, seus vetores, o meio ambiente e o próprio ser humano (FERREIRA, 1991). Dessa forma, acabou ampliando o poder analítico e explicativo de uma Geografia, antes restrita quase que exclusivamente à descrição do meio físico (LEMOS; LIMA, 2002). Segundo Ferreira (1991), ambos os esquemas conceituais são semelhantes porque partem de uma interpretação ecológica das relações entre o homem e o meio.

Com base nesse referencial, Rodrigues Júnior (2007, p. 9) apresenta a geoepidemiologia como um termo que procura:

Identificar uma evolução da epidemiologia que utiliza os referenciais teóricos do espaço geográfico, para construir modelos causais aperfeiçoados nas dimensões do meio ambiente físico e/ou humano, usando as técnicas de análise de dados e as tecnologias de informação, criando um elo colaborativo entre as ciências da saúde e a geografia. 
Dentre as tecnologias de informação referidas nessa definição, têm-se como exemplos os Sistemas de Informações Geográficas - SIG e as técnicas de Geoprocessamento.

\subsection{Geoprocessamento e Sistemas de Informações Geográficas (SIG)}

Geoprocessamento é definido por Barcellos et al. (2008) como um conjunto de tecnologias voltadas para a coleta e para o tratamento de informações espaciais com determinado objetivo, executadas por sistemas específicos para cada aplicação. Segundo Ramalho (2006), sua utilização na área de saúde é recente no Brasil. As primeiras aplicações, que se iniciaram na década de 1950, estiveram relacionadas principalmente ao planejamento urbano e às análises ambientais. Sua difusão no final dos anos 1980 e início da década de 1990 envolveu também a área de saúde, cujos profissionais passaram a explorá-los para o mapeamento digital, para a organização de dados espaciais e para a produção de mapas temáticos no contexto epidemiológico e da saúde pública.

Já os Sistemas de Informações Geográficas - SIG -, "são sistemas computacionais, usados para o entendimento dos fatos e fenômenos que ocorrem no espaço geográfico" (PINA, 1994, apud CARVALHO; PINA; SANTOS, 2000, p.14). Tais autores destacam como vantagem desses Sistemas sua capacidade de reunir, estruturar e integrar de forma adequada uma grande quantidade de dados convencionais de expressão espacial, o que os tornam importantes ferramentas de manipulação das informações geográficas.

De acordo com Aronoff (1995), os SIG armazenam e manipulam informação espacial utilizando um modelo de dados, ou seja, um conjunto de regras para converter dados geográficos reais em pontos, linhas, áreas ou em uma superfície contínua. Configura-se, portanto, uma abstração digital ou aproximação do mundo real. Santos e Barcellos (2006) expõem que, de forma geral, esses Sistemas permitem a realização de diversas funções conforme os objetivos de análise. Assim, em cada proposta, são definidas a unidade espacial, a escala e as variáveis a serem analisadas. 


\subsection{Lugar, espaço, território e saúde}

O médico Jonh Snow foi um dos principais responsáveis por considerar o atributo lugar nas análises de saúde. Em 1854, durante uma grave epidemia de cólera, ficou conhecido por mapear as residências de mortos pela doença e as bombas d'água que abasteciam as residências em Londres (SNOW,1990). Para Souza et al. (2005), a produção de mapas que permitam visualizar situações de saúde resultantes da interseção e da complementaridade de eventos é coerente com um conceito de vigilância em saúde de base territorial.

A categoria "espaço" e a análise de dados distribuídos pelo espaço geográfico vêm, então, sendo cada vez mais empregados no campo da saúde por apontar novos subsídios para o planejamento e a avaliação das ações. Seja por meio da distribuição espacial das doenças, seja pela localização dos serviços de saúde e até mesmo pela espacialização de indicadores socioeconômicos, sanitários e ambientais, tem sido possível conhecer as condições de vida das pessoas, o que é fundamental para a gestão em saúde (BARCELLOS; BASTOS, 1996; GONDIM et al., 2011).

Santos e Barcellos (2006) expõem, de forma concordante, que as análises realizadas com base em dados espaciais são importantes porque possibilitam ao pesquisador avaliar não só quantitativamente os dados, como também relacionar as informações de saúde com dados ambientais, socioeconômicos e com a posição que o evento ocupa na superfície terrestre. Para os autores, isso contribui para o acompanhamento das mudanças permanentes do espaço geográfico e para a detecção de áreas e populações sujeitas a agravos de saúde.

Outro conceito importante nesse contexto é o de territorialização. Segundo Monken e Barcellos (2005), esse conceito consiste num dos pressupostos da organização dos processos de trabalho e das práticas de saúde, considerando-se a atuação em uma delimitação espacial previamente determinada. A territorialização de atividades de saúde vem sendo preconizada por diversas iniciativas do Sistema Único de Saúde (SUS), como a Vigilância Ambiental em Saúde, Cidades Saudáveis, a própria descentralização das atividades de assistência e vigilância, e a Estratégia Saúde da Família. 


\subsection{Estratégia Saúde da Família e controle da Dengue}

Historicamente, a dispersão do Aedes aegypti não tem sido satisfatoriamente controlada com os métodos tradicionalmente empregados no combate às doenças transmitidas por vetores. No continente sul-americano, Programas essencialmente centrados no combate químico, com mínima participação da comunidade, sem integração intersetorial e com pequena utilização do instrumental epidemiológico, mostraram-se incapazes de conter um vetor com altíssima capacidade de adaptação ao novo ambiente criado pela urbanização acelerada e pelos novos hábitos (BRASIL, 2005).

Apesar de considerações que apontem para a eliminação do mosquito como praticamente inexequível nos dias de hoje, pela complexidade da vida urbana (TAUIL, 2002a), existem algumas formas de atuação que podem dar bons resultados. Segundo Chiaravalloti Neto et al. (2006), uma dessas alternativas é a integração do Programa de Controle do Dengue com o Programa Saúde da Família - PSF. O PSF, também reconhecido como Estratégia Saúde da Família - ESF -, foi implantado pelo Ministério da Saúde em 1994, com o propósito de reorganizar a prática da atenção à saúde em novas bases e substituir o modelo tradicional, levando a saúde para mais perto da família. Tal proposta prioriza as ações de vigilância, de prevenção, de promoção e de recuperação da saúde, de forma integral e contínua (BRASIL, 1998).

Em janeiro de 2002, o MS publicou a Portaria no 44/GM, que definiu e estabeleceu as atribuições do Agente Comunitário de Saúde - ACS - em relação à prevenção e ao controle do dengue (BRASIL, 2002b). Utilizando esse documento como um dos referenciais, um estudo conduzido num município do interior paulista mostrou que a integração entre os dois programas é viável, representa otimização de recursos ao evitar a duplicidade das visitas e possibilita um maior envolvimento da comunidade no controle do dengue (CHIARAVALLOTI NETO et al., 2006).

Iniciativas como essa são coerentes com o Plano Regional de Intensificação das Ações de Controle da Dengue no Mercosul, elaborado na XVII Reunião dos Ministros da Saúde do Mercosul e Estados Associados, no Rio de Janeiro em 2004 (REUNIÃO..., 2005). Nesse documento, foram elencados alguns aspectos essenciais para as mudanças necessárias ao enfrentamento da dengue. Dentre eles, dois procuram incitar, de forma mais direta, a participação da Comunidade e da 
Atenção Primária à Saúde: a) o desenvolvimento de campanhas de informação e de mobilização das pessoas, de maneira a criar uma maior responsabilização de cada família na manutenção de seu ambiente doméstico livre de potenciais criadouros do vetor; e b) a integração das ações de controle da dengue na atenção básica (REUNIÃO..., 2005).

Trabalhos recentes, nacionais e internacionais, têm considerado a importância da participação da atenção básica, ou atenção primária à saúde, na luta contra a dengue. Roriz-Cruz et al. (2010) apresentam que o município de Niterói-RJ assistiu a um aumento substancial na cobertura da Atenção Primária à Saúde nas duas últimas décadas, e que, paralelamente, foi observada uma redução significativa, não só da taxa de infestação domiciliar de Aedes aegypti, como também da incidência de casos de dengue durante esses anos. Por outro lado, na população do Rio de Janeiro-RJ, cuja cobertura de cuidados primários de saúde em 2008 era baixíssima, nenhuma mudança significativa foi observada, nos últimos 20 anos, em relação aos dois indicadores de dengue supracitados. Os autores não descartam algumas diferenças intermunicipais e outros possíveis determinantes da doença, mas acreditam que o diferencial positivo de Niterói-RJ foi a maior cobertura de atenção primária.

Já Ang, Rohani e Look (2010), num estudo transversal realizado num hospital na Malásia, identificaram que a maioria dos internados com suspeita de dengue procuraram atendimento nas unidades de atenção primária ainda na fase de viremia, representando, portanto, um risco de infectar o mosquito Aedes se fossem picados. Para os autores, uma vez que os pacientes sintomáticos passam a maior parte de seu tempo em casa durante a fase inicial da doença, essa seria uma excelente oportunidade para adotar medidas pós-infecção que interrompessem a cadeia de transmissão da dengue. Em especial, evitando ser picados pelos Aedes e tentando destruir os mosquitos adultos na residência.

Esses trabalhos indicam ainda que os profissionais de saúde atuantes na Atenção Primária devem ser considerados parceiros importantes na prevenção e no controle da dengue na comunidade. Por fim, Torres (2006) expõe de forma concordante que tanto a Atenção Primária à Saúde (APS) como a comunidade são espaços ideais para a gestão preventiva com base na educação em saúde e na busca ativa de casos. 


\subsection{Saúde, dengue e o contexto socioeconômico}

De acordo com Forattini (2004), os determinantes sociais são apresentados esquematicamente em duas categorias: os determinantes comportamentais e os organizacionais. Nessa segunda categoria, que se refere à organização da sociedade, os determinantes socioeconômicos são apresentados como parte dos determinantes estruturais. Para o autor, os determinantes socioeconômicos, que resultam do desenvolvimento econômico da sociedade e da forma como esta se organiza, podem levar a fatores que influenciam no surgimento de agravos.

Entretanto Kawamoto (1995), ao comentar sobre as interrelações entre saúde e desenvolvimento socioeconômico, apresenta que a ideia defendida por muitos de que o desenvolvimento corresponde à elevação da produtividade e da renda per capita nem sempre é real. Complementa que, em algumas situações, tal desenvolvimento acontece independentemente da melhoria do nível educacional e de saúde, principalmente quando utiliza recursos humanos desvitalizados por diversas condições doentias para esse progresso. Pereira (1995), ao discorrer sobre os modelos para representar fatores etiológicos, já apontava para a epidemiologia social, que visa a melhor compreensão dos fatores determinantes não biológicos na manutenção da saúde e na produção de doenças, como objeto de preocupação crescente de vários estudiosos.

Diversos trabalhos evidenciam que a situação socioeconômica desempenha um papel central na determinação da saúde (NUNES et al., 2001; DUARTE et al., 2002; apud COSTA; BARRETO; GIATTI, 2002). Por outro lado, o mecanismo exato da relação entre a composição do estado de saúde e da qualidade de vida da população não é tão bem definido, como observado nas palavras da pesquisadora Emília Emi Kawamoto: "a doença é causa e o efeito, ao mesmo tempo, da pobreza, da desnutrição, das más condições de habitação e da ignorância" (KAWAMOTO, 1995. p. 16).

No caso da re-emergência e da disseminação da dengue não é diferente. Tauil (2002b) afirma que, apesar das causas da mudança no comportamento epidemiológico da dengue ainda não estarem totalmente esclarecidas, é notável a associação de fatores demográficos, ecológicos e socioeconômicos à expansão da doença. Mondini e Chiaravalloyi Neto (2007) e Flauzino, Souza-Santos e Oliveira (2009) expõem que essa questão da relação entre transmissão de dengue e níveis 
socioeconômicos é controversa, citando vários estudos que apresentam resultados discordantes. Dentre os trabalhos que mostraram haver associação positiva entre maiores riscos de adquirir a doença e piores níveis socioeconômicos, tais autores destacam os achados de Siqueira et al. (2004), Caiaffa et al. (2005) e Barcellos et al. (2005). Já como exemplos em que esse tipo de correlação não foi encontrada, citam os resultados de Vasconcelos et al. (1998), Teixeira et al. (2002) e Espinoza-Gomés et al. (2003), dentre outros.

Assim, à luz dos conceitos de "foco natural de doença" de Pavlovsky, inspirado na geografia física, e de "complexo patogênico" de Sorre, fundamentado na geografia humana, acredita-se que o controle da dengue dependa de intervenções que transcendam o setor saúde. Portanto, exige, como descreve Tauil (2002b), ações que visem à melhoria das condições de vida, principalmente na área de educação, habitação e saneamento básico. Diante disso, esperou-se que esse trabalho fornecesse dados geoepidemiológicos sobre a incidência de dengue na área urbana de Alfenas-MG, a partir da caracterização do perfil epidemiológico dos casos confirmados, da distribuição espacial das residências desses indivíduos e da descrição da relação entre os níveis socioeconômicos e a presença desse agravo na comunidade. 


\section{OBJETIVOS}

\subsection{Objetivo geral}

Investigar a incidência de dengue da área urbana de Alfenas - MG entre 2001 e 2010.

\subsection{Objetivos específicos}

- Caracterizar os casos confirmados de dengue segundo as variáveis: faixa etária, sexo, raça e escolaridade;

- Verificar a distribuição espacial dos casos pelos bairros e áreas de PSF urbanos do Município;

- Agrupar os setores censitários por nível socioeconômico e descrever a densidade de casos de dengue pelos grupos. 


\section{MATERIAL E MÉTODOS}

\section{1 Área de estudo}

A área de estudo foi constituída pela região urbanizada do Município de Alfenas que localiza-se a 455' $50^{\circ}$ " W de longitude e $21^{\circ} 25^{\prime} 45^{\prime \prime} \mathrm{S}$ de latitude, na região Sul do Estado de Minas Gerais, a cerca de $340 \mathrm{~km}$ da capital mineira - Belo Horizonte - e 306 km de São Paulo-SP. Ocupa uma área de 849,2 $\mathrm{Km}^{2}$ de extensão, com altitude máxima 888m acima do nível do mar, na cabeceira do Córrego Mateus Cego, e a mínima de 768m, na represa de Furnas. Articula-se em uma malha rodoviária com três estradas federais (BR-491, BR-267 e BR-369), algumas estaduais (MG-179, MG-184, MG-453 e MG-879), e diversas municipais. Contém 75.214 habitantes, segundo estimativas populacionais para o TCU do Instituto Brasileiro de Geografia e Estatística - IBGE (BRASIL, 2009b).

\subsection{Delineamento do estudo}

Trata-se de um estudo transversal com abordagem descritiva. Segundo Passos e Ruffino-Neto (2011), os estudos transversais também são conhecidos como estudos seccionais ou de corte transversal e podem ser classificados como analíticos ou descritivos. De acordo com Pereira (1995), as investigações epidemiológicas de cunho descritivo, como a realizada neste trabalho, têm o objetivo de informar sobre a distribuição de um evento na população, em termos quantitativos. Já Franco (2011), expõe que os dados descritivos constituem elementos importantes para a avaliação das condições de saúde de uma comunidade, orientando as ações a serem desenvolvidas.

\subsection{Coleta, tratamento e análise dos dados}

Os dados sobre as notificações de casos autóctones de dengue, referentes ao período de janeiro de 2001 a dezembro de 2010, das áreas urbana e rural do 
Município de Alfenas-MG, foram coletados no Setor de Vigilância Epidemiológica da Secretaria Municipal de Saúde de Alfenas-MG. A fonte de dados, portanto, foi o banco de dados descentralizado do Sistema de Informação de Agravos de Notificação - Sinan -, no nível municipal (BRASIL, 2006). Levantaram-se 19 variáveis de interesse relativas à "pessoa", ao "tempo" e ao "lugar", escolhidas, levando-se em conta os objetivos do estudo e a disponibilidade dos dados:

- Pessoa: Raça; Escolaridade; Sexo; Data de nascimento; Número da notificação; Resultado da sorologia; Classificação final; Critério utilizado para conclusão da investigação; Evolução.

- Tempo: Data dos primeiros sintomas; Data da notificação; Data da investigação; Data da sorologia; Data de Encerramento da investigação.

- Lugar: Código do município de residência; Bairro de residência; Tipo do logradouro de residência; Nome do logradouro de residência; Número da residência.

Entretanto, para tecer a caraterização dos casos, concentrou-se nos registros cuja classificação final apontou para a confirmação de dengue clássico. Os dados que indicavam sujeitos residentes na área rural não foram considerados devido ao fato de a proposta inicial ser a de se trabalhar com a área urbana de Alfenas-MG. Assim, foi criado um banco de dados utilizando o Software Acess 2010, a partir do qual deu-se início à descrição da distribuição simples e relativa das variáveis de interesse, com o auxílio do Software Stata 9.0 (STATA, 2011).

Em relação ao tempo, levou-se em conta a "data dos primeiros sintomas" para descrever a distribuição da incidência de dengue segundo os meses. Para o cálculo do coeficiente, adotou-se como numerador o número de casos confirmados do mês e, como denominador, a população estimada daquele ano, segundo projeções intercensitárias do IBGE, disponíveis no DATASUS (BRASIL, 2009b). Esse resultado foi multiplicado por 100.000 que é a base referencial da população.

Já a base cartográfica com os lotes geocodificados e o banco de dados contendo os endereços do Município, foram disponibilizadas pelo Setor de Geoprocessamento da Secretaria Municipal da Fazenda de Alfenas-MG. Skaba (2009), ao abordar metodologias de geocodificação dos dados da saúde, afirma que a eficiência desse processo depende da qualidade dos dados de endereço captados 
nos sistemas de informações em saúde, da cobertura e da atualização do cadastro de endereços utilizado e da capacidade do próprio programa em relacionar essas bases de dados, levando em consideração possíveis erros e formas de grafia de endereços.

Esse autor lembra que o endereço, por ser uma informação textual, precisa de um tratamento para ter condições de ser utilizado em um sistema computacional, incorporado a um SIG e servir de componente de uma estatística espacial para as análises necessárias. Dessa forma, para satisfazer o objetivo de espacializar os dados, percorreram-se várias etapas preliminares de preparação dos arquivos. Antes de utilizar os dados colhidos, foi necessário uniformizar os endereços dos casos notificados de dengue segundo o banco de dados de logradouros do Município de Alfenas-MG.

Esse tratamento foi composto por: (1) Normalização - que consistiu em tratar abreviaturas, espaços e caracteres especiais; (2) Separação -, em tipo de logradouro, título, nome, número, complemento, além de bairro, cidade e outras referências; e (3) Padronização - que objetiva igualar a tabela ao formato do banco de dados base (SKABA, 2009). Após essas etapas, o endereço ficou pronto para a comparação com a bases de dados dos endereços disponíveis.

O Software Acess 2010 foi utilizado para criar um Banco de Dados no formato "Microsoft Access Database (.mdb)", a partir do qual foi possível importar ambas as planilhas. Por meio da ferramenta "Criar"_ "Design da Consulta", conseguiu-se relacionar as bases tabulares, vinculando as varáveis "Tipo de Logradouro" (AVE, RUA, TRA, etc), "Nome do Logradouro" (AFONSO PENA, por exemplo) e "Número da Residência", comuns aos dois registros e gerar uma nova planilha. Nesta última, pôde-se observar não somente as variáveis de interesse contidas nas fichas de notificação de dengue do Sinan, como também os endereços dos indivíduos investigados e, o mais importante para o próximo passo do trabalho, os códigos utilizados pela Secretaria de Planejamento para identificar os lotes do Município.

Em seguida, foi criado um Banco de Dados no ambiente do Sistema de Informação Geográfica - SIG Terra View, versão 3.2.0, desenvolvido pelo Instituto Nacional de Pesquisas Espaciais - INPE (TERRAVIEW, 2010) e deu-se início à etapa de ligação da base tabular com a base cartográfica dos lotes geocodificados do Município. Por meio desse processo, foi possível importar para o SIG dados de 326 fichas de forma automática, o que correspondeu a $68,48 \%$ do total de registros 
da área urbana. Já atentando-se para os casos confirmados, foi possível geocodificar $80,22 \%$ dos endereços por meio de ligação automática, o que equivaleu a 142 fichas de casos de dengue clássico.

Nessa etapa, grandes esforços foram despendidos para alcançar o melhor percentual de endereços geocodificados. Tais atividades incluíram comparação entre endereços antigos e atuais, consulta à ferramenta Google Maps e a mapas com os nomes dos logradouros confeccionados em data anterior ao período de estudo (GOOGLE MAPS, 2011). Essas ações configuraram-se demoradas, laborosas, mas importantes para a aproximação almejada de 100\% dos endereços geolocalizados. Assim, acredita-se que a perda observada foi devida à não conformidade de parte dos geoobjetos (polígonos), referentes ao lotes com a planilha de logradouros do Município.

Em posse do Banco de Dados Geocodificados, deu-se início a uma série de consultas com o SIG Terra View. Por meio da ferramenta "Consulta por Atributos" (OLIVEIRA et al., 2007), foi possível microlocalizar os locais de residência e gerar uma nova vista com os polígonos de lotes ocupados pelas pessoas acometidas por dengue. A partir dessa vista foi criado um novo plano ao qual foram atribuídas representações de centroides. Tais centroides foram convertidos em pontos, utilizando-se a opção de exportação vetorial do SIG, que gerou um novo arquivo "Shapefile". Dessa maneira, conseguiu-se gerar mapas de pontos referentes às residências em que ocorreram casos autóctones de dengue clássico em AlfenasMG, de 2001 a 2010, e dar início às análises espaciais desses eventos.

Segundo Bailey e Gatrell (1995), o padrão de pontos é considerado o modo mais simples de representar dados espaciais. Traçar os casos em um mapa, com cada ponto representando um caso, de acordo com Gordis (2004), é uma abordagem muito útil para examinar diferenças geográficas ou espaciais da ocorrência de eventos. Esse mesmo enfoque é o que Medronho e Werneck (2005), e Barcellos, Silva e Andrade (2007), classificam como análise espacial dos eventos por meio da visualização de dados espaciais.

Já para verificar se a localização dos lotes de domicílios com indivíduos infectados ocorreu aleatoriamente ou se houve algum padrão de distribuição sistemático pelo território, foi adotada uma mescla bastante utilizada de dois procedimentos de análise espacial de eventos, mencionada por Barcellos, Silva e Andrade (2007), a "visualização-exploratória". Nessa perspectiva, buscou-se uma 
integração dos procedimentos de visualização, ou seja, das ferramentas usadas para mapear dados espacialmente georreferenciados, com os procedimentos exploratórios, que analisam os dados na tentativa de detectar padrões, identificar aglomerados, etc (BARCELLOS; SILVA; ANDRADE, 2007). Outra análise realizada foi a da densidade de pontos que, segundo Gatrell e Bailey (1996) apud Oliveira et al. (2007), tem na estimativa Kernel a técnica mais conhecida e mais utilizada para estimar densidade de eventos. Para tais autores, o seu emprego desempenha um papel importante no contexto epidemiológico para identificar a concentração de casos.

A estimativa de Kernel é uma técnica de interpolação exploratória que gera uma superfície de densidade para a identificação visual de "áreas quentes", isto é, uma densidade a partir da qual se considera que os pontos formam um aglomerado. Assim, produz uma superfície contínua, com densidades calculadas em todas as localizações, poupando o investigador de definir, de forma arbitrária, onde "cortar" a "área quente". Essa técnica apresenta, como uma das maiores vantagens, a rápida visualização de áreas que merecem atenção, além de não ser afetada por divisões político-administrativas. Desse modo, tal estimador de intensidade constitui uma boa alternativa para se avaliar o comportamento dos padrões de pontos em uma determinada área de estudo, sendo considerado muito útil para fornecer uma visão geral da distribuição de primeira ordem dos eventos (BARCELLOS; SILVA; ANDRADE, 2007; CARVALHO; CÂMARA, 2004).

Nessa técnica, utilizou-se a unidade de agregação "bairros" como região de suporte; uma grade de 500 colunas; os pontos correspondentes às residências dos casos confirmados como eventos; a função quártico para o cálculo de densidade e um raio de 300 metros. Esse valor para o raio foi considerado com base na dispersão das fêmeas de Aedes aegypti (SOUZA-SANTOS; CARVALHO, 2000). Apesar de estas não voarem mais que cem metros normalmente, Trpis et al. (1995) lembram que elas podem aumentar seu raio de dispersão à procura de um lugar para pôr seus ovos, caso não existam criadouros apropriados no local. Os resultados da análise espacial de eventos e da análise da densidade de pontos foram sobrepostos ao cartograma com a divisão de bairros do Município e das áreas urbanas adstritas da Estratégia Saúde da Família. Para a geração dos mapas, foi utilizado o SIG Terra View.

Já para a caracterização dos níveis socioeconômicos do Município, utilizou-se 
Estatística Multivariada. Pereira (2001, p. 102) resume análise multivariada como "qualquer abordagem analítica que considere o comportamento de muitas variáveis simultaneamente". Nesse contexto, análise de agrupamentos é o termo utilizado para definir um grupo de técnicas multivariadas em que o objetivo principal é agregar objetos, levando em conta as suas características (HAIR et al., 2005). De acordo com Ferreira (2008), o interesse em agrupar objetos, em determinadas situações, pode ser alterado para a intenção de agrupar variáveis. De qualquer modo, há consenso quanto ao que se espera nesse tipo de análise exploratória: a classificação de diversas entidades em um número reduzido de grupos mutuamente excludentes. Em outras palavras, os agrupamentos resultantes deverão exibir elevada homogeneidade interna e elevada heterogeneidade externa (HAIR et al., 2005; MINGOTI, 2005; FERREIRA, 2008).

Segundo Pereira (2001) e Hair et al. (2005), para executar a análise de agrupamentos, realizam-se como procedimentos:

1) o cálculo das distâncias euclidianas entre os objetos e variáveis consideradas (como medida de similaridade e para determinar a quantidade de grupos);

2) a sequência de agrupamentos por proximidade geométrica, que se constitui no próprio processo de agrupamento (composto por procedimento hierárquico e método aglomerativo);

3) e, por último, o reconhecimento dos passos de aglomeração e identificação coerente dos grupos (para a escolha do número de agrupamentos na solução final).

Ferreira (2008), ao discorrer sobre as propriedades dos diversos métodos de agrupamento hierárquico, cita Rencher (2002), ao expor que os métodos de Ward e da ligação média, apesar de não apresentarem robustez e alta sensibilidade às observações discrepantes como nos métodos centroide e do vizinho mais distante, possuem os melhores desempenhos de uma maneira geral. Assim, no presente estudo, o método do Agrupamento Hierárquico de Ward (MINGOTI, 2005), foi empregado para caracterizar o Município quanto ao contexto socioeconômico. Para tanto, foi elaborado um dendograma, segundo Hair et al. (2005) e Ferreira (2008), 
por meio do pacote estatístico Stata versão 9.0, com parâmetros calculados a partir das variáveis relacionadas ao saneamento ambiental, às condições de renda, à escolaridade e ao adensamento populacional do Censo Demográfico de 2000 (IBGE, 2011):

- Média dos anos de instrução das pessoas responsáveis pelos domicílios;

- Média dos anos de instrução das mulheres responsáveis pelos domicílios;

- Renda média (em reais) das pessoas responsáveis pelos domicílios;

- Renda média (em reais) das mulheres responsáveis pelos domicílios;

- Proporção de pessoas responsáveis analfabetas (\%);

- Proporção de mulheres responsáveis analfabetas (\%);

- Proporção de domicílios com 5 ou mais moradores (\%);

- Proporção de domicílios com água encanada (\%);

- Proporção de domicílios com esgotamento sanitário (\%);

- Proporção de domicílios com coleta regular de lixo (\%).

A utilização desses parâmetros se fundamentou nos trabalhos de Vendramini et al. (2006) e Mondini e Chiaravalloti Neto (2007), que estudaram a relação entre a ocorrência de duas importantes doenças transmissíveis e o contexto socioeconômico na escala submunicipal. Já a escolha dos setores censitários como objetos a serem agrupados, esteve fundamentada na experiência de Mondini e de Chiaravalloti Neto (2007), que, apesar de terem utilizado outro tipo de análise multivariada (a Análise de Componentes Principais), consideraram esse nível de agregação por ser delimitado geograficamente e por apresentar características homogêneas.

Os dados do agrupamento foram exportados para o banco de dados geocodificados no TerraView e foram incrementados com os resultados da análise espacial, ou seja, o mapa de pontos e os mapas de Kernel com as densidades de casos confirmados de dengue em Alfenas, de 2001 a 2010. Pretendeu-se com essa análise exploratório-descritiva levantar hipóteses sobre a associação de fatores sociais, ambientais e econômicos na incidência da doença no Município. 


\subsection{Procedimentos éticos}

A coleta de dados foi autorizada pela Secretaria de Saúde da Prefeitura Municipal de Alfenas-MG, conforme documento do Apêndice II. O projeto foi aprovado pelo Comitê de Ética em Pesquisa da Universidade Federal de Alfenas UNIFAL-MG, conforme apresentado no Apêndice III. Foram utilizados dados secundários, portanto, sem aplicação do Termo de Consentimento Livre e Esclarecido, mantendo-se a garantia de sigilo. 


\section{RESULTADOS}

Havia no Sinan registro de 489 notificações de dengue referentes à década estudada. Do total de fichas, 476 remetiam a pessoas com moradia urbana $(97,34 \%)$ e 13 registros indicavam sujeitos residentes na área rural (2,66\%). Nas notificações de casos urbanos, percebeu-se que 37,18\% resultaram na confirmação de dengue clássico, o que correspondeu a 177 indivíduos. Por outro lado, 61,34\% dos casos suspeitos foram descartados, representando 292 pessoas; $1,26 \%$ dos registros foram classificados como inconclusivos (06 indivíduos), e 0,21\%, equivalente a uma pessoa, não teve a classificação final informada. Não houve caso confirmado na zona rural, nem óbito como desfecho de caso; todos os acometidos evoluíram para a cura.

Notou-se que em $83,82 \%$ das notificações o critério de confirmação/descarte foi o laboratorial (399 fichas); em $14,71 \%$ das suspeitas, o critério foi o clínicoepidemiológico (70 fichas), e, em 1,47\% das notificações, não foi encontrada essa informação (07 fichas). Sobre os exames sorológicos, 162 foram classificados como reagente (34,03\%); 234 , como não reagente $(49,16 \%)$; em 55 casos, os exames não foram realizados (11,55\%); e, em 25 notificações, esse dado não foi informado $(5,25 \%)$. A seguir, uma representação tabular do quantitativo de notificações de dengue, conforme a evolução temporal e a classificação final das investigações (Tabela 1).

TABELA 1 - Distribuição das notificações de dengue e classificação final das investigações no Município de Alfenas, de 2001 a 2010.

\begin{tabular}{ccccccccccc}
\hline \multirow{2}{*}{ Ano } & \multicolumn{2}{c}{ Casos Confirmados } & \multicolumn{2}{c}{ Descartados } & \multicolumn{3}{c}{ Inconclusivos } & \multicolumn{2}{c}{ Não Informados } & \multicolumn{2}{c}{ Total de Notificações } \\
& $\mathrm{n}$ & $\%$ & $\mathrm{n}$ & $\%$ & $\mathrm{n}$ & $\%$ & $\mathrm{n}$ & $\%$ & $\mathrm{n}$ & $\%$ \\
\hline 2001 & 1,0 & 0,6 & 2,0 & 0,7 & 0,0 & 0,0 & 0,0 & 0,0 & 3,0 & 0,6 \\
2002 & 106,0 & 59,9 & 77,0 & 26,4 & 1,0 & 16,7 & 0,0 & 0,0 & 184,0 & 38,7 \\
2003 & 2,0 & 1,1 & 26,0 & 8,9 & 0,0 & 0,0 & 0,0 & 0,0 & 28,0 & 5,9 \\
2004 & 0,0 & 0,0 & 4,0 & 1,4 & 0,0 & 0,0 & 0,0 & 0,0 & 4,0 & 0,8 \\
2005 & 0,0 & 0,0 & 6,0 & 2,1 & 0,0 & 0,0 & 0,0 & 0,0 & 6,0 & 1,3 \\
2006 & 11,0 & 6,2 & 32,0 & 11,0 & 5,0 & 83,3 & 0,0 & 0,0 & 48,0 & 10,1 \\
2007 & 23,0 & 13,0 & 59,0 & 20,2 & 0,0 & 0,0 & 0,0 & 0,0 & 82,0 & 17,2 \\
2008 & 2,0 & 1,1 & 28,0 & 9,6 & 0,0 & 0,0 & 1,0 & 100,0 & 31,0 & 6,5 \\
2009 & 0,0 & 0,0 & 24,0 & 8,2 & 0,0 & 0,0 & 0,0 & 0,0 & 24,0 & 5,0 \\
2010 & 32,0 & 18,1 & 34,0 & 11,6 & 0,0 & 0,0 & 0,0 & 0,0 & 66,0 & 13,9 \\
\hline Total & 177,0 & 100,0 & 292,0 & 100,0 & 6,0 & 100,0 & 1,0 & 100,0 & 476,0 & 100,0 \\
\hline
\end{tabular}

Fonte: do autor. 
No que se refere ao sexo, as mulheres apresentaram o maior número de casos confirmados, com 90 pessoas, ou seja, $50,85 \%$ do total. Já do sexo masculino, foram diagnosticados 87 indivíduos, o correspondente a $49.15 \%$. Em relação à faixa etária, o maior percentual de casos foi observado nos indivíduos com idade entre 20 e 29 anos (26,55\%), seguidos pelas pessoas com 30 a 39 anos $(22,60 \%)$. Ao se adotar a classificação por ciclos de vida, percebeu-se que os mais acometidos foram os adultos, ultrapassando a $75 \%$ dos casos confirmados. Em seguida, foram as crianças e adolescentes e, por fim, os idosos.

Ainda atentando para as cacterísticas de "pessoa", percebeu-se que, dentre os 177 indivíduos com a suspeita confirmada, predominaram os de raça branca $(89,27 \%)$, seguidos pelos de raças parda $(4,52 \%)$ e preta $(3.39 \%)$, respectivamente. Olhando para o perfil de escolaridade dessas pessoas, notou-se que os extremos configuraram a menor porcentagem dos casos. Não houve registro de indivíduos analfabetos nem de pessoas com nível de educação superior completo. Em contrapartida, destacou-se com maior frequência a escolaridade Ensino fundamental completo. Tais distribuições podem ser visualizadas na Tabela 2. 
TABELA 2 - Caracterização dos casos confirmados de dengue no Município de Alfenas-MG, entre 2001 e 2010, segundo faixa etária, sexo, raça e escolaridade.

\begin{tabular}{|c|c|c|c|c|}
\hline \multirow{2}{*}{\multicolumn{2}{|c|}{ Casos confirmados de dengue clássico }} & \multicolumn{3}{|c|}{ Notificações } \\
\hline & & \multirow{2}{*}{$\frac{n}{87,00}$} & \multirow{2}{*}{$\begin{array}{c}\% \\
49,15\end{array}$} & \multirow{2}{*}{$\frac{\% \text { acum. }}{49,15}$} \\
\hline Sexo & Masculino & & & \\
\hline & Feminino & 90,00 & 50,85 & 100,00 \\
\hline \multirow[t]{7}{*}{ Raça } & Branca & 158,00 & 89,27 & 89,27 \\
\hline & Preta & 6,00 & 3,39 & 92,66 \\
\hline & Amarela & 0,00 & 0,00 & 92,66 \\
\hline & Parda & 8,00 & 4,52 & 97,18 \\
\hline & Indíginena & 0,00 & 0,00 & 97,18 \\
\hline & Ignorada & 3,00 & 1,69 & 98,87 \\
\hline & Não informada & 2,00 & 1,13 & 100,00 \\
\hline \multirow[t]{12}{*}{ Escolaridade } & Analfabeto & 0,00 & 0,00 & 0,00 \\
\hline & $1^{\underline{a}}$ a $4^{\underline{a}}$ série incompleta do EF & 3,00 & 1,69 & 1,69 \\
\hline & $4^{\mathrm{a}}$ série completa do EF & 10,00 & 5,65 & 7,34 \\
\hline & $5^{\mathrm{a}}$ a $8^{\mathrm{a}}$ série incompleta do EF & 38,00 & 21,47 & 28,31 \\
\hline & Ensino fundamental completo & 47,00 & 26,55 & 55,37 \\
\hline & Ensino médio incompleto & 36,00 & 20,34 & 75,71 \\
\hline & Ensino médio completo & 5,00 & 2,82 & 78,73 \\
\hline & Educação superior incompleta & 6,00 & 3,39 & 81,92 \\
\hline & Educação superior completa & 0,00 & 0,00 & 81,92 \\
\hline & Ignorada & 22,00 & 12,43 & 94,35 \\
\hline & Não se aplica & 1,00 & 0,56 & 94,92 \\
\hline & Não informada & 9,00 & 5,08 & 100,00 \\
\hline \multirow[t]{10}{*}{ Faixa etária } & 5 a 9 anos & 2,00 & 1,13 & 1,13 \\
\hline & 10 a 14 anos & 10,00 & 5,65 & 6,78 \\
\hline & 15 a 19 anos & 13,00 & 7,34 & 14,12 \\
\hline & 20 a 29 anos & 47,00 & 26,55 & 40,68 \\
\hline & 30 a 39 anos & 40,00 & 22,60 & 63,28 \\
\hline & 40 a 49 anos & 24,00 & 13,56 & 76,84 \\
\hline & 50 a 59 anos & 23,00 & 12,99 & 89,83 \\
\hline & 60 a 69 anos & 13,00 & 7,34 & 97,18 \\
\hline & 70 a 79 anos & 4,00 & 2,26 & 99,44 \\
\hline & 80 anos e mais & 1,00 & 0,56 & 100,00 \\
\hline
\end{tabular}

Fonte: do autor. 
Já em relação ao tempo, pôde-se perceber que os meses com os maiores coeficientes de incidência, de modo geral, foram os de março, abril e maio. No ano de 2002, esse período se estendeu até o mês de junho. Em outros anos, como os de 2003 e 2006, houve ainda discreta elevação desse índice nos meses de janeiro e novembro, conforme apresentado na Figura 1.

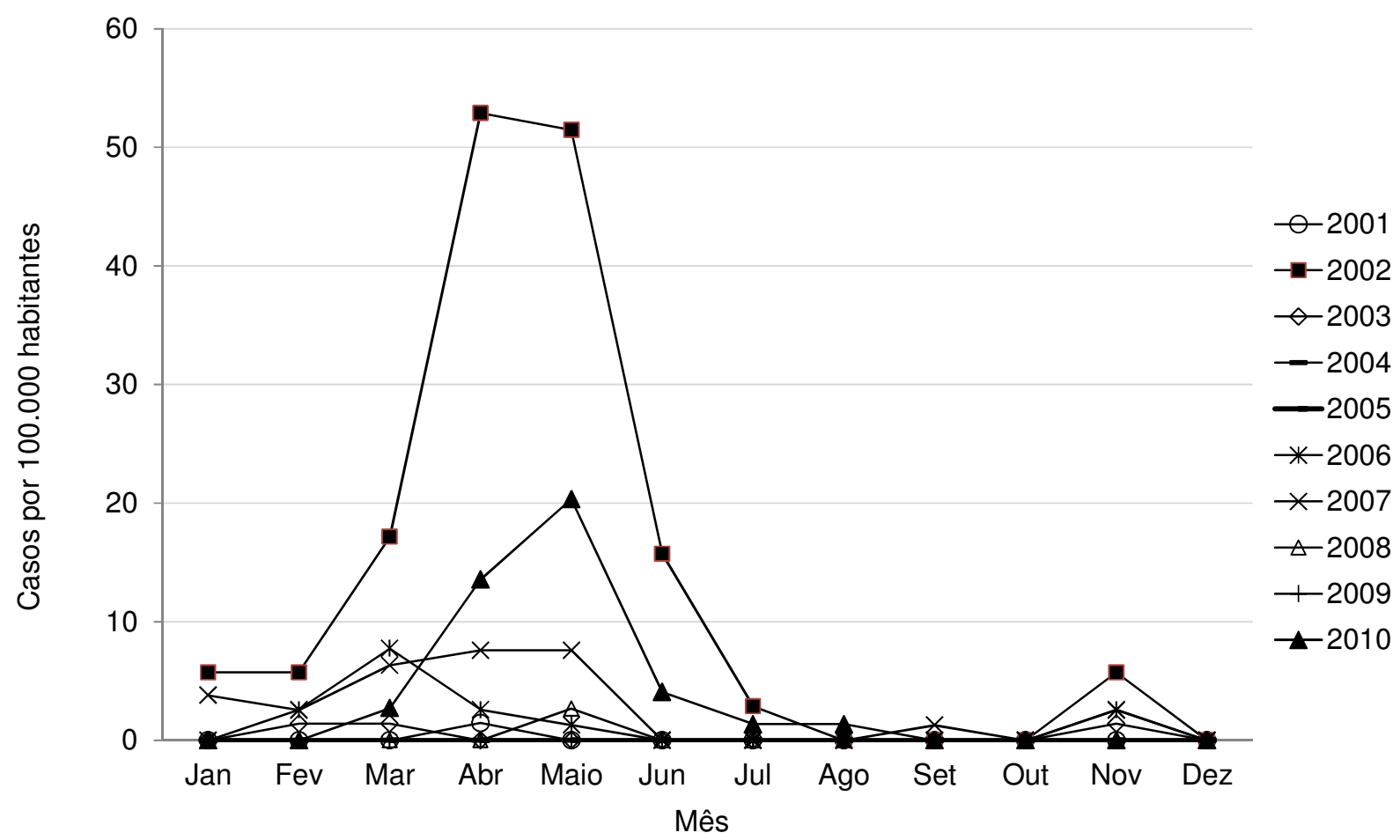

FIGURA 1 - Coeficientes de incidência de dengue em Alfenas-MG, segundo meses, de 2001 a 2010. Fonte: do autor.

No que se refere ao lugar, o mapa de pontos, referentes aos locais de residência dos casos confirmados, sugere, de forma empírica, uma distribuição menos frequente da dengue nas áreas periféricas do Município, com aparentes aglomerações de casos nas regiões mais centrais, conforme mostra a Figura 2. 


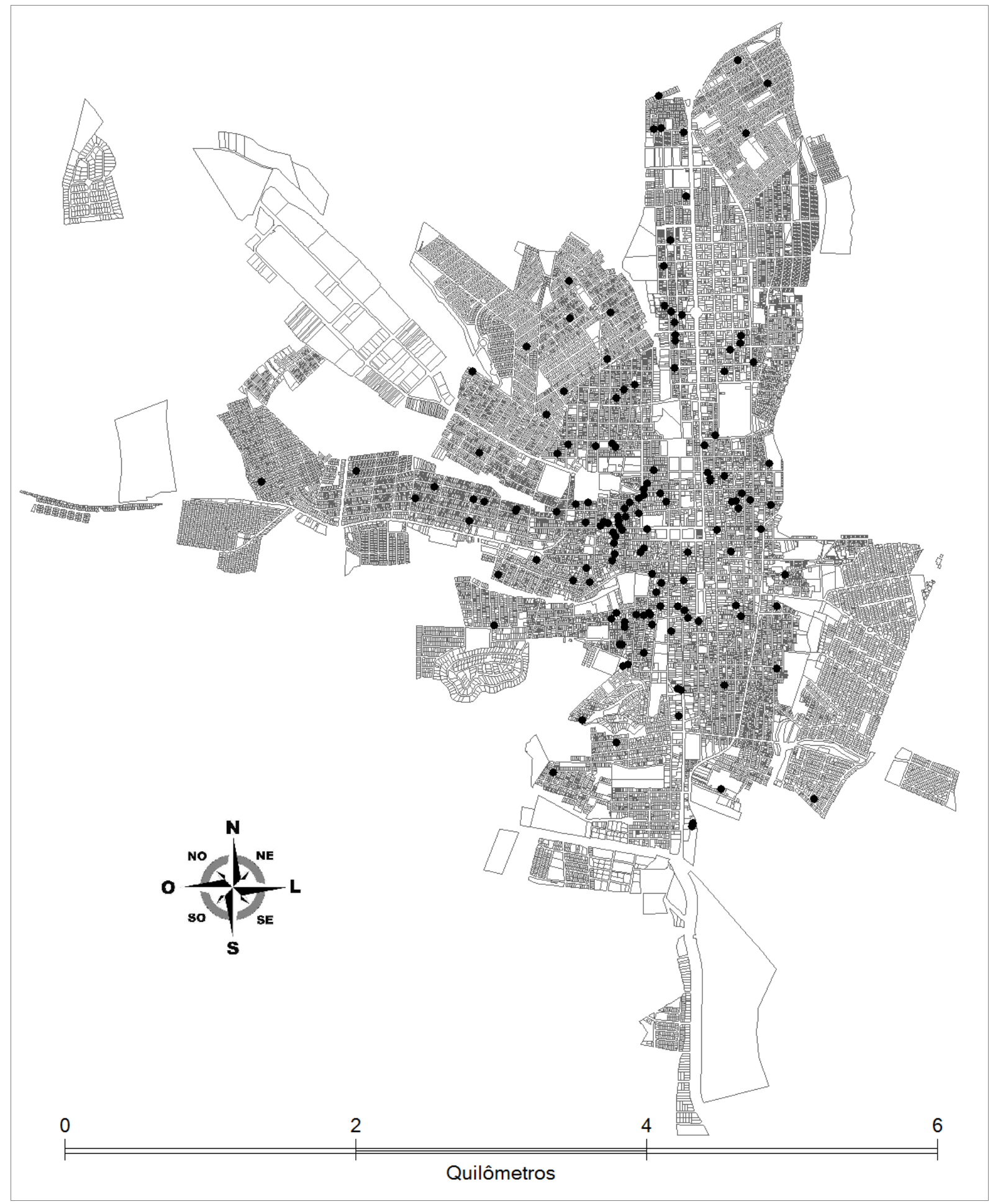

FIGURA 2 - Mapa de pontos referentes às residências em que ocorreram casos autóctones de dengue clássico na área urbana de Alfenas-MG, de 2001 a 2010.

Fonte: do autor.

Pensado na ocorrência da doença nos bairros, a técnica de Kernel mostrou que o local de residência dos casos confirmados de dengue no Município seguiu uma distribuição espacial bastante heterogênea pela área urbana. Nessa análise de 
padrões pontuais, foi possível visualizar que, entre os anos de 2001 e 2010, houve diversos aglomerados pelo território. Entretanto, a não repetição de concentrações nos locais anteriormente atingidos foi um achado interessante.

No ano de 2001, a área que apresentou maior concentração de casos foi a região sudeste do bairro Vila Betânia. Com intensidade um pouco menor, concentraram-se casos na região noroeste do Centro da cidade e na região nordeste do bairro Aparecida. Já em 2002, período epidêmico de maior expressão de casos no Município, o bairro mais afetado foi o Aparecida. Nas suas regiões central e leste, foram encontrados os maiores valores de Kernel para a década estudada. Com menor densidade, mas com distribuição semelhante, perceberam-se casos na região sudoeste e noroeste do bairro Centro. Nesse ano, também chamou a atenção a concentração de casos na região central do Bairro Jardim Boa Esperança e norte da Vila Godoy.

No ano subsequente, 2003, as áreas mais atingidas foram a região nordeste do Centro e noroeste do Jardim Panorama. Concentrações menores foram percebidas da região sudoeste do bairro Chapada, no leste do Jardim Santa Inês e na região sul do bairro Vista Alegre. Densidade de casos bem mais discreta, porém não menos importante, pôde ser vista no nordeste do bairro Vila Santa Maria e na região noroeste da Vila Teixeira. Para os anos de 2004 e 2005, a estimativa de Kernel não apontou áreas quentes, uma vez que não houve casos confirmados. Em 2006, a região sudoeste do Jardim São Carlos foi a que apresentou maior densidade de casos, seguida pelo Centro (com residências nas regiões nordeste e noroeste do bairro), Cruz Preta (com concentração na região nordeste do bairro) e região leste do próprio Jardim São Carlos.

O ano de 2007 foi o primeiro período a chamar a atenção pela dispersão de vários aglomerados no território urbano. Valores de Kernel mais expressivos foram encontrados nas regiões sul do bairro Vista Grande e norte do Jardim São Carlos. Em seguida, destacaram-se as regiões norte da Vila Betânia, nordeste do bairro Aparecida e noroeste do Centro. Já com densidade ainda menor, despontaram os bairros: Jardim América, Pôr-do-sol, Jardim São Carlos, Vila Santa Edwirges, Vila Santa Luzia, Chapada, Vista Alegre, Jardim Santa Inês, Jardim Boa Esperança, Centro, Aparecida, Vila Betânia, Residencial Oliveira, Morada do Sol e Recreio Vale do Sol. No ano de 2008, destacaram-se as regiões norte do Centro, sul do Jardim São Carlos, bem como a região sudoeste do bairro Estação. De forma mais branda, 
foi acometido o norte do Vila Formosa. Em 2009, como também em 2004 e 2005, não foi identificada concentração, devido à ausência de casos de dengue.

Por fim, no último ano da série, o número de aglomerados e a dispersão destes pelo Município foram parecidos com os achados de 2007. Contudo, os valores de Kernel e o locais onde se concentraram os casos em 2010 não foram coincidentes. As regiões norte e nordeste do bairro Centro apresentaram a maior densidade de casos do ano. Em seguida destacaram-se o sudoeste do bairro Chapada, o norte do Jardim Primavera e o sudoeste do Centro. Já com valores mais discretos, puderam-se detectar diversas aglomerações distribuídas pelos bairros: Jardim São Carlos, Jardim América, Nova América, Vila Betânia, Jardim Boa Esperança, Pôr-do-sol, Vila São Vicente, Vista Alegre e Residencial São Lucas. Essas observações foram dispostas de forma gráfica, por meio dos mapas de Kernel, acrescidos dos pontos que correspondem aos casos de dengue entre os anos de 2001 a 2010, conforme apresenta a Figura 3. 

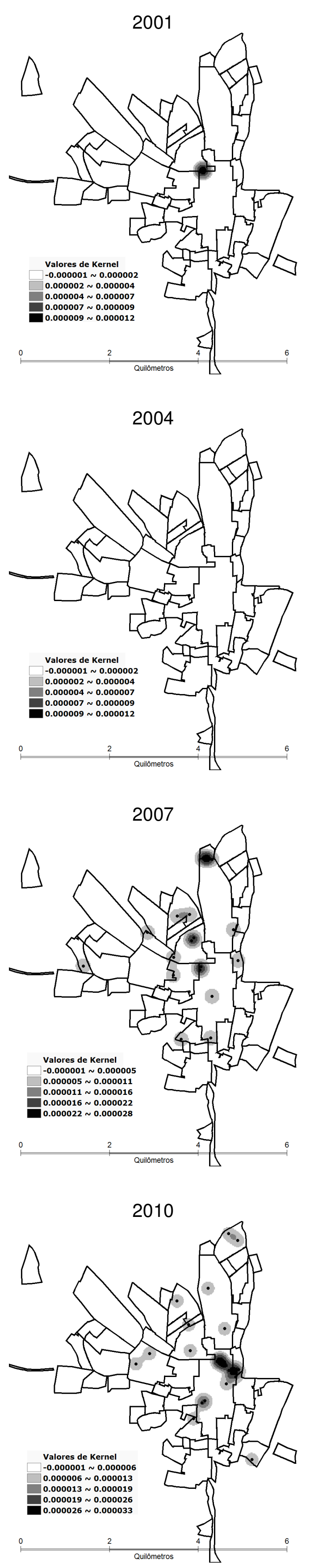
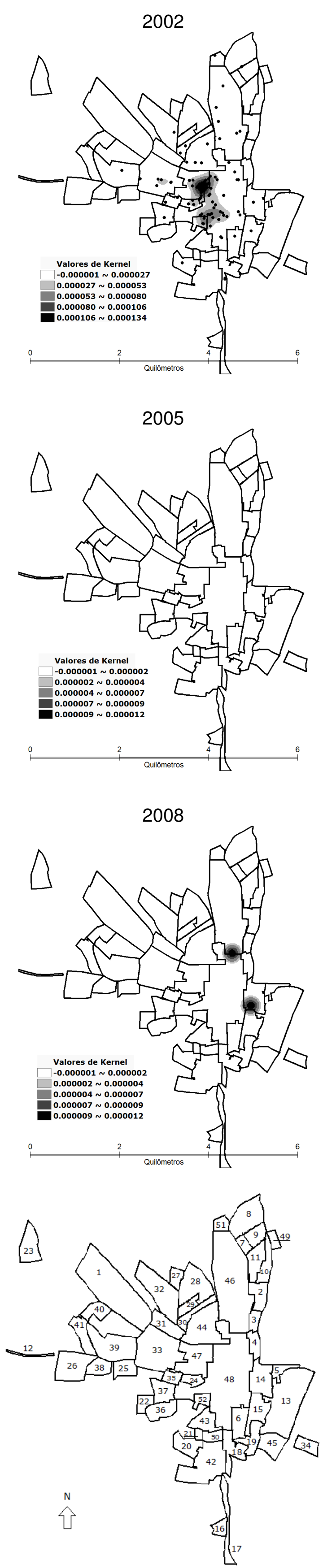
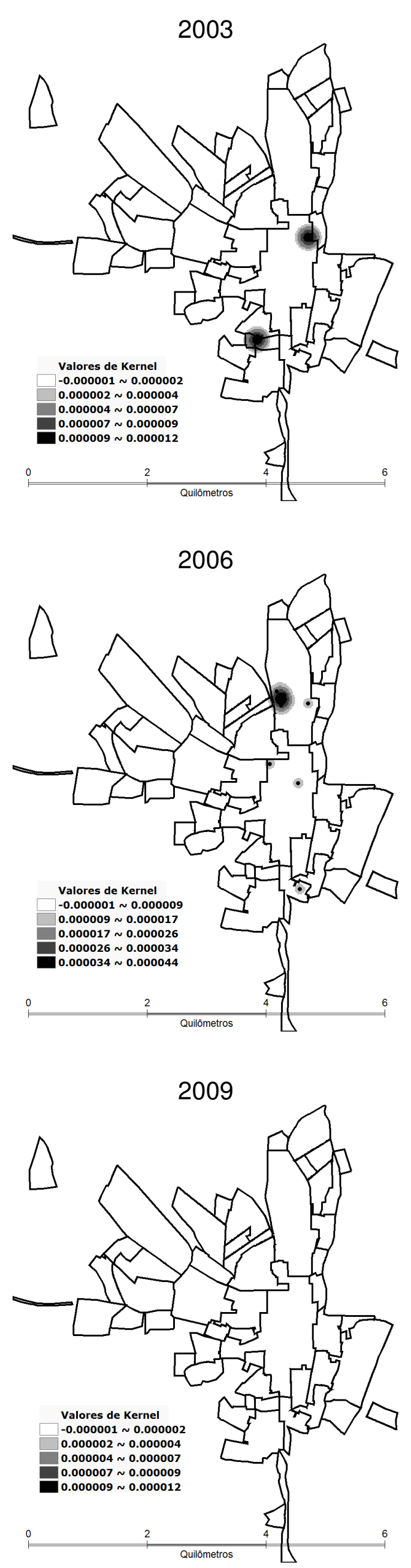

\section{Legenda:}

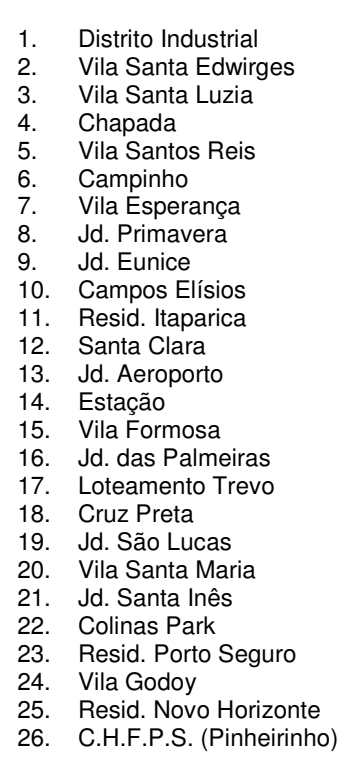

27. Pôr-do-Sol 29. Conj. Hab. Pôr-do-Sol
29. Améra 30. Jd. Nova América 31. Morada do Sol

32. Resid. Oliveira

33. Jd. Boa Esperança
34. Resid. Alto do Aeroporto 34. Resid. Alto do
35. Jd. Elite 35. Jd. Elite
36. Jd. da Colina 37. Jd. Tropical 38. Resid. Vale Verde 39. Jd. Alvorada 40. Jd. São Paulo 41. Recreio Vale do 42. Vila Teixeira
43. Vista Alegre 44. Vila Betânia 45. Resid. São Lucas 46. Jardim São Carlos 47. Aparecida 48. Centro 49. Vila Promessa 50. Jd. Panorama 52. Vila São Vicente 
O Município de Alfenas-MG conta atualmente com 13 equipes da Estratégia Saúde da Família, sendo 12 equipes urbanas e uma de atuação na zona rural, que totalizam mais de $60 \%$ de cobertura da população. Entretanto, a implantação dessas Unidades foi feita de forma gradual e teve início no ano de $2002 \mathrm{com}$ oito Equipes. Em 2004, inaugurou-se a nona Unidade; no ano de 2006, a primeira Equipe de ESF Rural e a décima ESF Urbana; e, em 2008 e 2010, as últimas Unidades com atendimento na área urbana.

A distribuição espacial dos casos, segundo as áreas urbanas cobertas por essa Estratégia, revela que na maioria dos anos da série os aglomerados de casos de dengue identificados não coincidiram com as regiões adstritas das Unidades de Saúde da Família.

No ano de 2002, período epidêmico, percebeu-se concentração de casos bastante expressiva na divisa da região nordeste do PSF Aparecida II com a região mais central do Município. Em 2007, com menor densidade, identificou-se concentração de casos na região leste do PSF Primavera. De forma mais discreta, notou-se também um aglomerado na região central do PSF Vila Betânia. Nesse ano, que figurou uma das situações de maior dispersão de casos pelo território, puderamse observar ainda baixos valores de Kernel nas áreas dos PSF São Carlos, Aparecida II e Recreio Vale do Sol. Já no ano de 2008, o local que mais chamou a atenção em relação à concentração de casos foi a região sul do PSF Santos Reis.

Outro ano com distribuição espacial de casos bastante heterogênea, o de 2010, apresentou aglomeração de casos na região sul do PSF São Carlos, na divisa com a região norte do PSF Santos Reis e em parte do centro de Alfenas. Entretanto, mesmo nesses quatro anos em que foi possível identificar concentrações de casos em parte das áreas cobertas pelas Equipes descritas, a predominância de aglomerados ocorreu nas regiões sem a atuação da Estratégia Saúde da Família. A Figura 4 apresenta mapas de Kernel com os aglomerados de casos de dengue e as áreas de PSFs urbanos. 

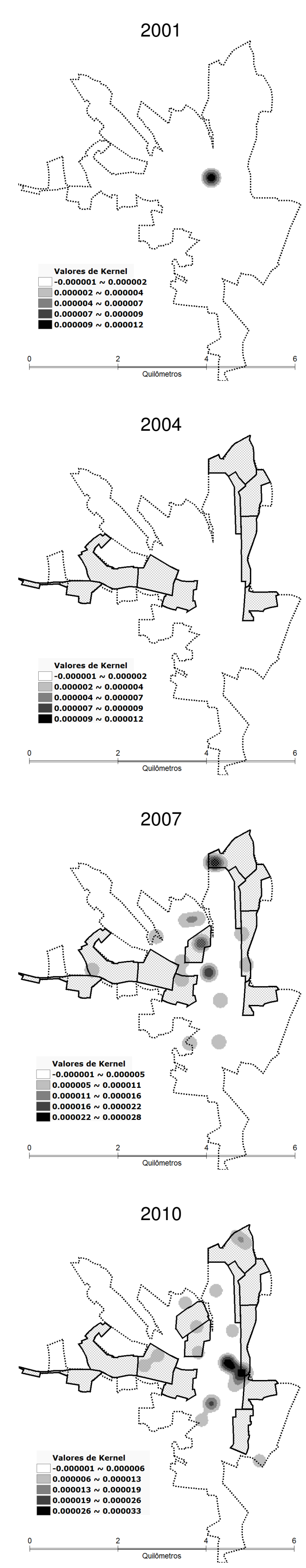
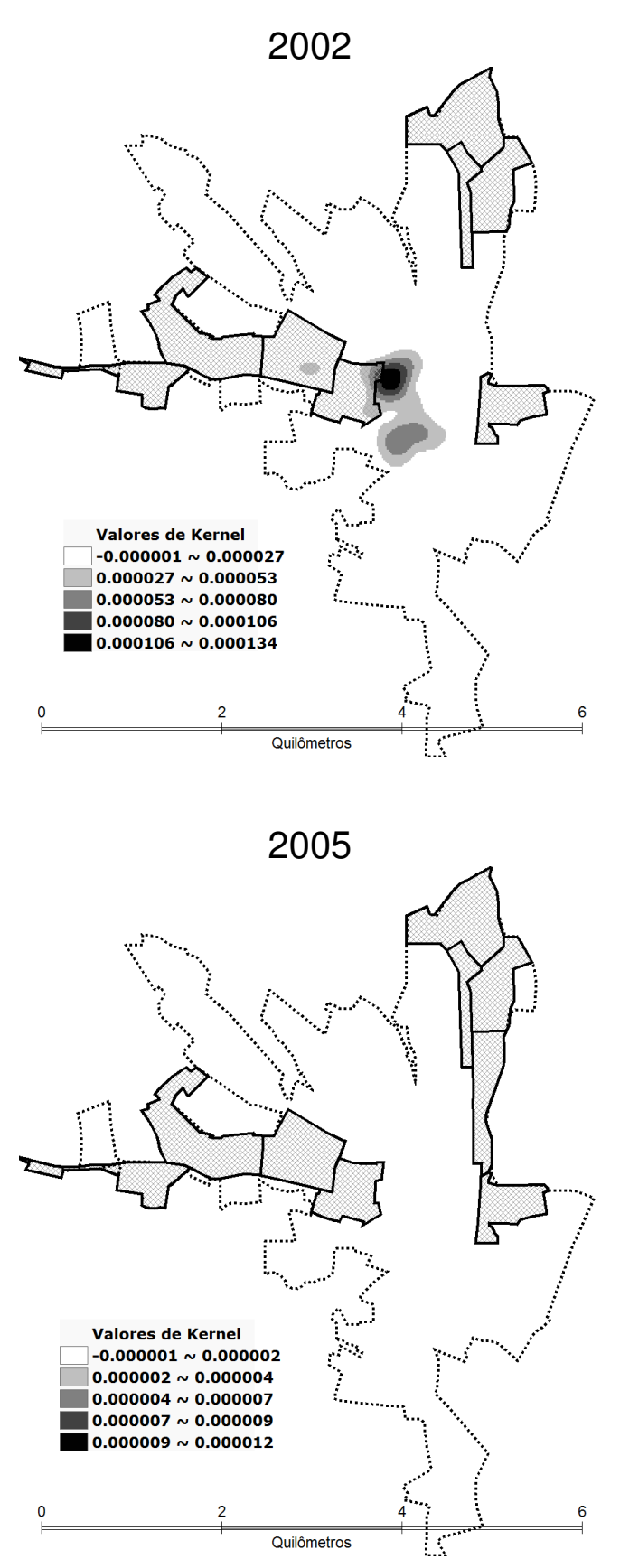

2008
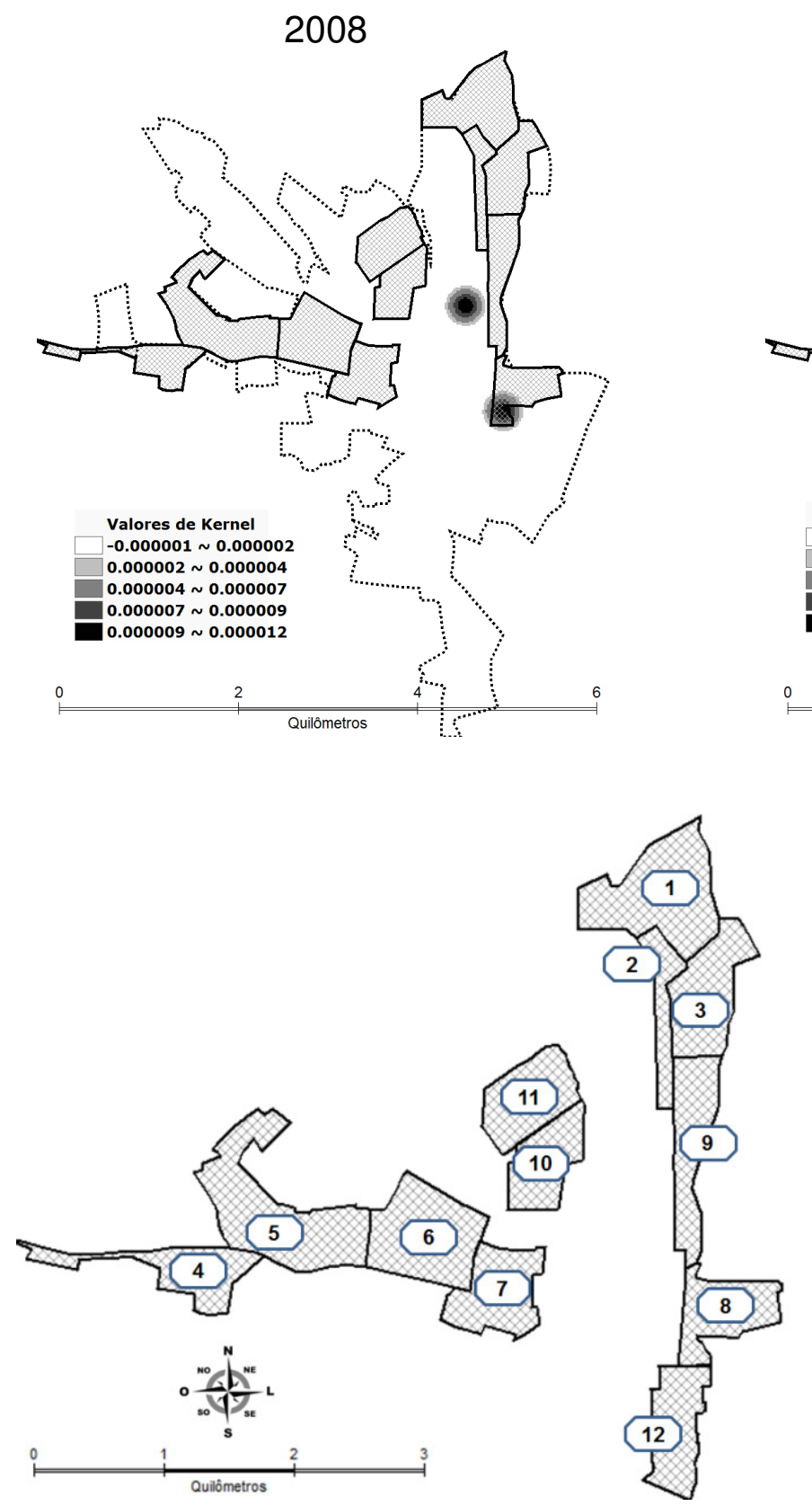

2003

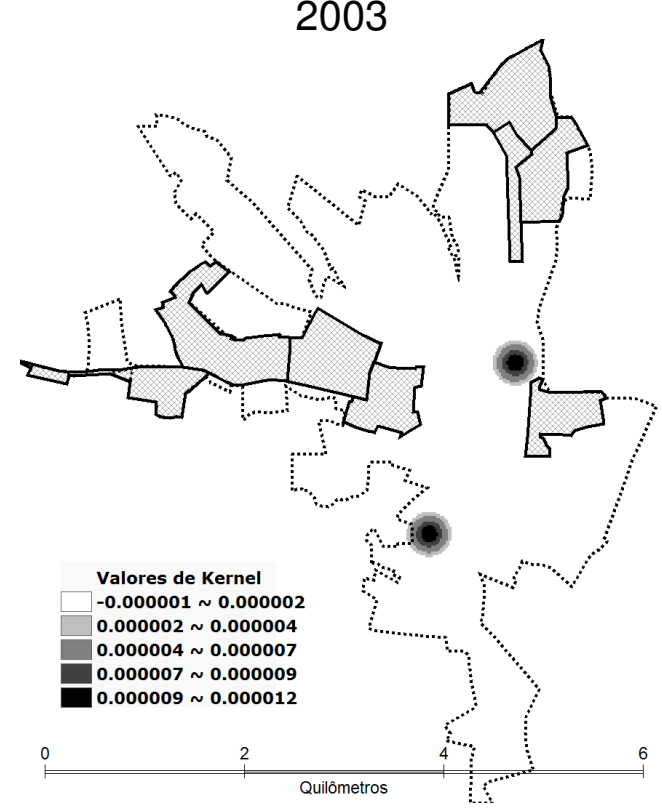

2006

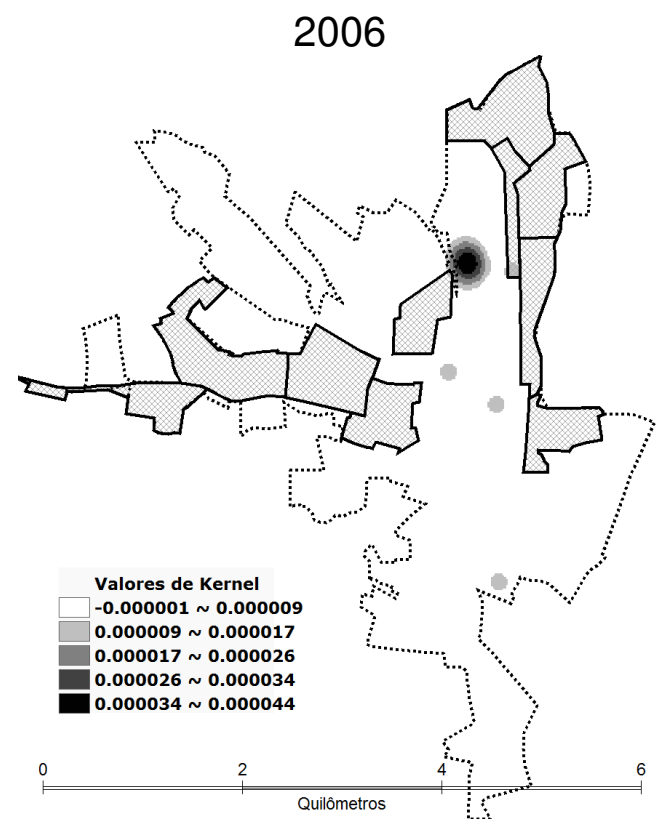

2009

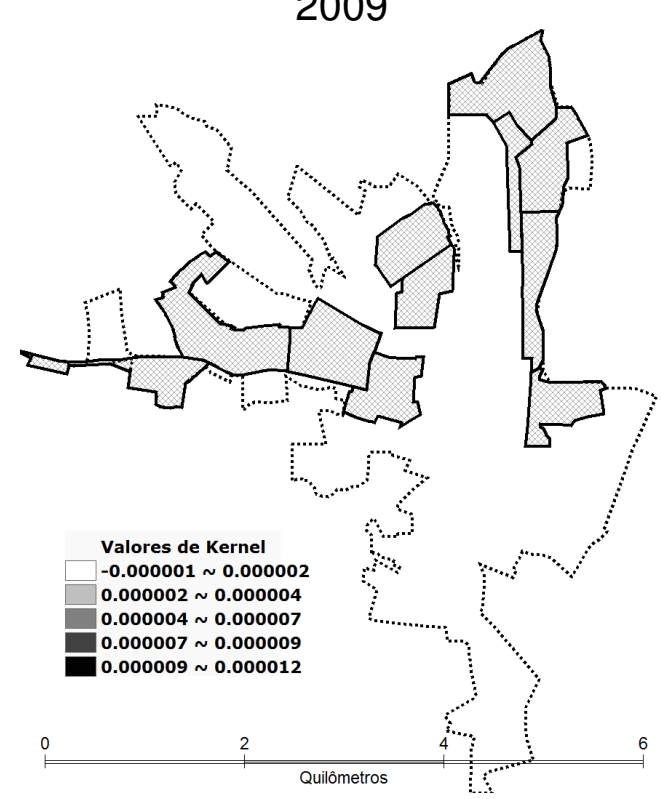

Legenda:

1 - PSF Primavera (2002)

2 - PSF São Carlos (2002)

3 - PSF Itaparica (2002)

4 - PSF Pinheirinho (2002)

5 - PSF Rec. Vale do Sol (2002)

6 - PSF Boa Esperança (2002)

7 - PSF Aparecida II (2002)

8 - PSF Santos Reis (2002)

9 - PSF Unisaúde (2004)

10 - PSF Vila Betânia (2006)

11 - PSF Nova América (2008)

12 - PSF Vila Formosa (2010) 
De acordo com o Instituto Brasileiro de Geografia e Estatística - IBGE, O município de Alfenas-MG conta com 70 setores censitários urbanos, pelos quais se distribuem residências de todas as classes sociais. Na Análise de Cluster optou-se, empiricamente, pelo agrupamento das unidades censitárias em quatro grupos. $\mathrm{Na}$ Figura 5 é apresentado o dendograma, onde pode ser visualizado o ponte de corte assumido para agrupar os setores conforme os parâmetros socioeconômicos.

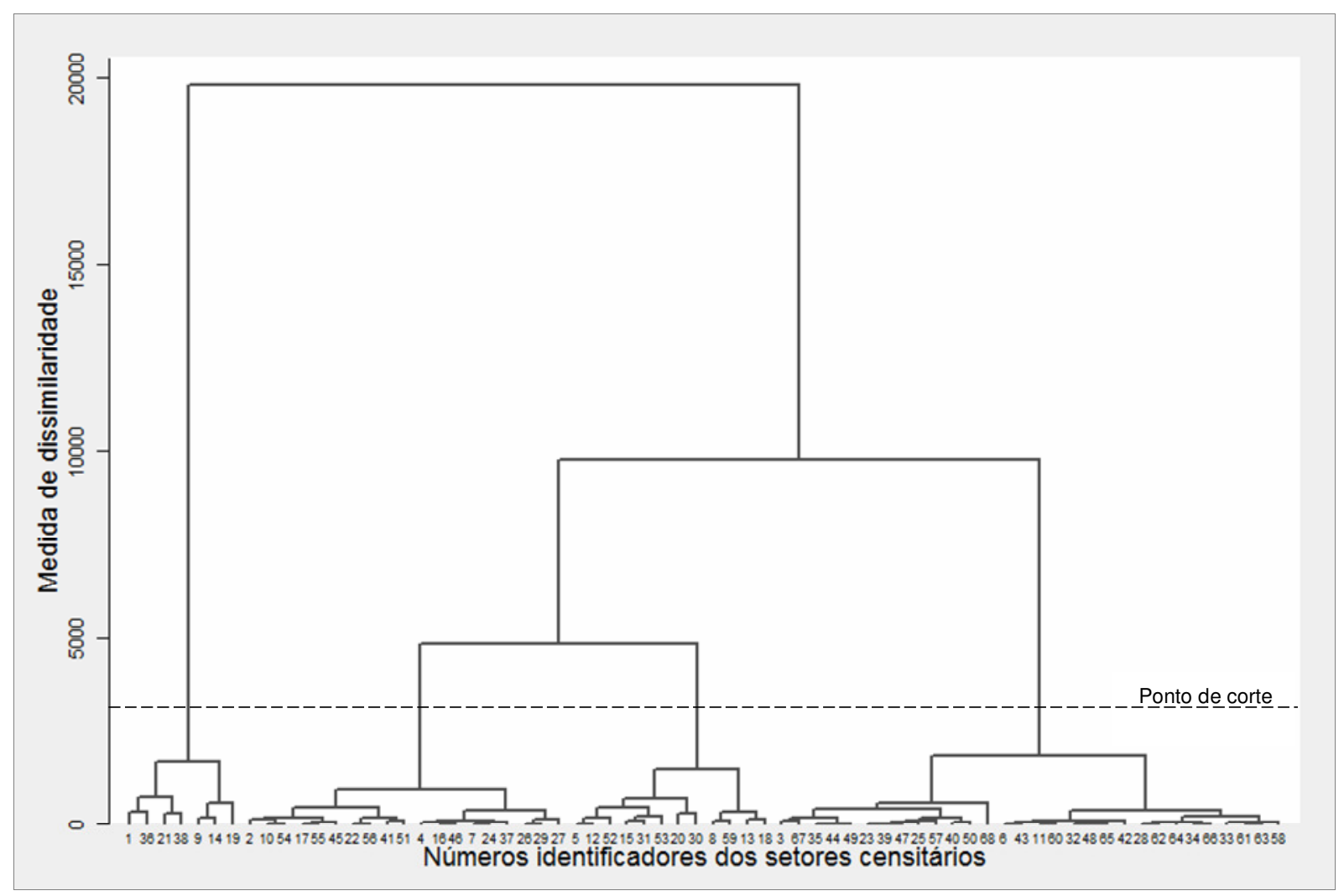

FIGURA 5 - Dendograma para Análise de Cluster, elaborado pelo método do Agrupamento Hierárquico de Ward.

Fonte: do autor.

Os setores de número 04 e 70 foram excluídos de forma automática no momento do agrupamento hierárquico e aparecem nos resultados como "sem informação" socioeconômica. Seus parâmetros não foram calculados devido à falta de informação de algumas variáveis do Censo. O setor 04 é um setor especial que foi considerado pelo IBGE como "Setor especial de asilos, orfanatos, conventos, hospitais, etc. sendo constituído de no mínimo 50 moradores". Essa classificação confere com o convento e o ambulatório de especialidades existentes nessa área. Já 
no setor 70, existe um Residencial à beira do Lago de Furnas, chamado Porto Seguro, em que não há dados da variável "V1138 - Mulheres responsáveis por domicílios particulares permanentes". A ausência dessa informação interferiu anulando os parâmetros "Média dos anos de instrução das mulheres responsáveis pelos domicílios"; "Renda média (em reais*) das mulheres responsáveis pelos domicílios"; "Proporção de mulheres responsáveis analfabetas (\%)". Além disso, outros parâmetros que apresentaram valor zero foram: "Proporção de domicílios com 5 ou mais moradores (\%)"; "Proporção de domicílios com água encanada (\%)"; "Proporção de domicílios com esgotamento sanitário (\%)" e "Proporção de domicílios com coleta regular de lixo (\%).

Ao término desse agrupamento, os valores médios dos parâmetros socioeconômicos dos setores que compunham cada cluster foram calculados, com a finalidade de classificá-los quanto ao nível socioeconômico. Dessa forma, o cluster que apresentou valores maiores foi considerado como de melhor nível socioeconômico, o grupo com valores menores foi classificado como pior extrato socioeconômico e os demais agrupamentos configuraram os níveis socioeconômicos intermediários. A partir desse critério, as unidades censitárias do cluster 1 passaram a compor o nível socioeconômico 1; os setores do grupo 4 figuraram o nível socioeconômico 4 e os setores dos grupos 2 e 3 foram denominados nível socioeconômico 3 e nível socioeconômico 2, respectivamente (Tabela 3). 
TABELA 3 - Valores médios dos parâmetros socioeconômicos utilizados para classificar os setores censitários e clusters quanto ao nível socioeconômico.

\begin{tabular}{|c|c|c|c|c|}
\hline \multirow{3}{*}{ Parâmetros socioeconômicos } & \multicolumn{4}{|c|}{ Média dos parâmetros socioeconômicos } \\
\hline & Cluster 1 & Cluster 2 & Cluster 3 & Cluster 4 \\
\hline & $\begin{array}{l}\text { Nível socio- } \\
\text { econômico } 1\end{array}$ & $\begin{array}{l}\text { Nível socio- } \\
\text { econômico } 3\end{array}$ & $\begin{array}{l}\text { Nível socio- } \\
\text { econômico } 2\end{array}$ & $\begin{array}{l}\text { Nível socio- } \\
\text { econômico } 4 \\
\end{array}$ \\
\hline $\begin{array}{l}\text { Média dos anos de instrução das pessoas } \\
\text { responsáveis pelos domicílios }\end{array}$ & 10,8433 & 6,6461 & 8,0189 & 4,5949 \\
\hline $\begin{array}{l}\text { Média dos anos de instrução das mulheres } \\
\text { responsáveis pelos domicílios }\end{array}$ & 10,1084 & 6,2823 & 7,5964 & 3,8330 \\
\hline $\begin{array}{l}\text { Renda média (em reais*) das pessoas } \\
\text { responsáveis pelos domicílios }\end{array}$ & 2392,6266 & 748,9242 & 1158,2868 & 452,5712 \\
\hline $\begin{array}{l}\text { Renda média (em reais*) das mulheres } \\
\text { responsáveis pelos domicílios }\end{array}$ & 1548,3713 & 460,9510 & 810,8538 & 262,9662 \\
\hline $\begin{array}{l}\text { Proporção de pessoas responsáveis } \\
\text { analfabetas (\%) }\end{array}$ & 0,0145 & 0,0751 & 0,0394 & 0,1525 \\
\hline $\begin{array}{l}\text { Proporção de mulheres responsáveis } \\
\text { analfabetas (\%) }\end{array}$ & 0,0186 & 0,1306 & 0,0693 & 0,2383 \\
\hline $\begin{array}{l}\text { Proporção de domicílios com } 5 \text { ou mais } \\
\text { moradores (\%) }\end{array}$ & 0,2170 & 0,2441 & 0,2186 & 0,2960 \\
\hline $\begin{array}{l}\text { Proporção de domicílios com água } \\
\text { encanada }(\%)\end{array}$ & 0,9970 & 0,9959 & 0,9981 & 0,9524 \\
\hline $\begin{array}{l}\text { Proporção de domicílios com esgotamento } \\
\text { sanitário (\%) }\end{array}$ & 0,9953 & 0,9914 & 0,9970 & 0,9322 \\
\hline $\begin{array}{l}\text { Proporção de domicílios com coleta regular } \\
\text { de lixo (\%) }\end{array}$ & 0,9986 & 0,9943 & 0,9973 & 0,9466 \\
\hline
\end{tabular}

Fonte: do autor.

No que se refere ao lugar, a visualização espacial dos setores segundo essa classificação socioeconômica sugere que os locais de residência dos casos confirmados de dengue se distribuíram de forma independe ao extrato a que pertenciam. Ora os aglomerados se situaram em setores com melhor condição socioeconômica, ora em regiões menos favorecidas e, na maioria das vezes, as concentrações de casos ocorreram nas divisas entre unidades censitárias de níveis distintos.

No ano de 2001, o aglomerado de casos aconteceu nos limites entre os setores censitários de número 27, 28 (nível socioeconômico 3) e 10 (nível 
socioeconômico 1), com valores de Kernel mais altos no setor 27. Em 2002, ano que apresentou a maior densidade de casos da série, os setores da região central do município foram os mais atingidos. O setor 8 foi o que apresentou maior concentração (nível socioeconômico 3), seguido pelo setor 9 (nível socioeconômico 2). Já com menor intensidade, foram atingidos outros setores do nível socioeconômico 3, como o 27, o 46 e o 2; áreas de nível socioeconômico 2, como os setores 6 e 19; de nível socioeconômico 4, como os setores de número 3 e 7; e de forma mais discreta em setores de melhor nível socioeconômico, como o 1, 15 e 10, também se observou concentração de casos.

No terceiro ano do período estudado, 2003, observaram-se duas aglomerações. A primeira se situou na divisa dos setores 11 (nível socioeconômico 3); 13 (nível socioeconômico 2); 12 e 35 (nível socioeconômico 4), com densidade maior entre os setores 12 e 13. Já a segunda aglomeração, ocorreu na divisa do setor 20 (nível socioeconômico 1 e valor de Kernel mais alto), com o setor 21, de nível socioeconômico 2 e menor densidade de casos. Para os anos de 2004 e 2005, não foram observados aglomerados de casos.

Já em 2006, as concentrações de casos de dengue ocorreram com maior frequência em setores de nível socioeconômico 2 como os de número 13, 31, 32; seguidos pelos setores 27, 30 e 42 do grupo socioeconômico 3; entretanto a região que apresentou maior densidade de casos foi a limítrofe dos setores 31 (nível socioeconômico 2) e 58 de nível socioeconômico 4.

No ano de 2007, o aglomerado mais expressivo foi devido a uma concentração de casos no setor 59, próximo ao setor de número 65 (ambos de nível socioeconômico mais baixo). Outras aglomerações importantes puderam ser vistas nos setores 29 e 27, dos extratos socioeconômicos 4 e 3 respectivamente. Casos confirmados mais dispersos pelos setores 1 e 20 , de melhor condição socioeconômica; 55 e 56, de nível socioeconômico 3; setor 32, do $2^{\circ}$ extrato; e 24, 35, 49 e 50 de nível socioeconômico mais baixo, também contribuíram para a identificação de áreas quentes. Nesse ano, pôde-se perceber que a distribuição dos casos foi predominante nos setores menos favorecidos socioeconomicamente.

Em 2008, casos nos setores 34 (nível socioeconômico 4) e 38 (nível socioeconômico 3), com aglomeração mais evidente, contribuíram para a estimação de valores de Kernel menos expressivos para os setores 11 e 28 (nível 
socioeconômico 3); e unidades censitárias 14, 15 e 36, dos extratos socioeconômicos 2, 1 e 4.

Já em 2010, a área que mais chamou a atenção foi a composta pelos setores 10, 11, 12, 13 e 35, com todos os níveis socioeconômicos representados. Com densidade menor, concentraram-se casos entre os setores 1 e 2 (níveis socioeconômicos 1 e 3); e, entre as unidades do extrato socioeconômico 4, setores 66 e 67. Houve ainda distribuição espacial de casos bastante heterogênea pelo território, com confirmação de dengue nos setores 58, 55, 57, 32, 26, 20, 68, 14, 47 e 51, dos quatro grupos socioeconômicos.

Para ilustrar a densidade de casos de dengue pelos distintos grupos socioeconômicos, os dados da análise espacial realizada em primeira ordem foram subpostos a mapas temáticos, conforme apresentado na Figura 6. As imagens do cruzamento entre as estimativas de Kernel e a malha de setores, segundo o nível socioeconômico, dos anos de 2004, 2005 e 2009, não foram expostas, uma vez que nesses períodos não houve registro de casos confirmados de dengue. 

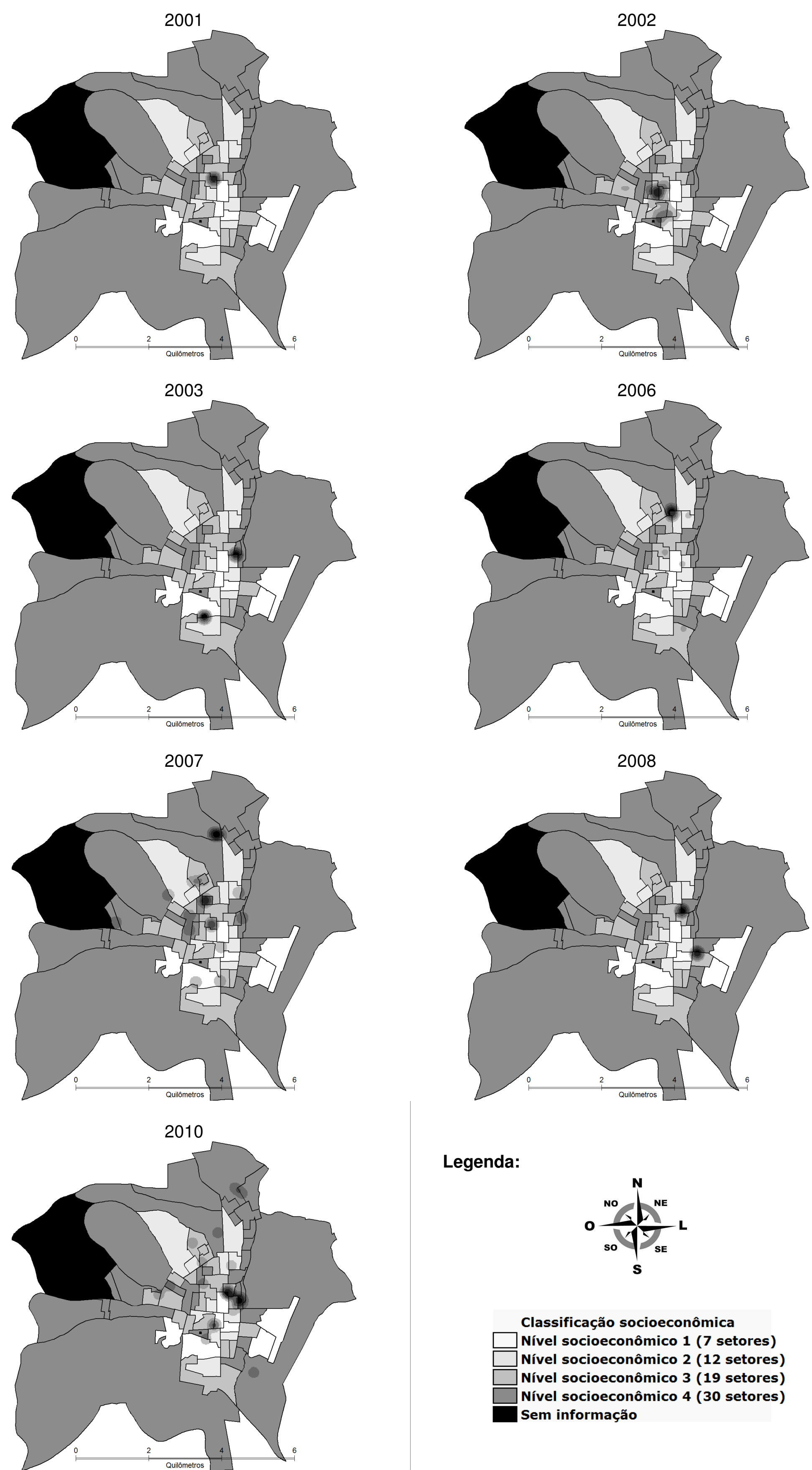

\section{Legenda:}

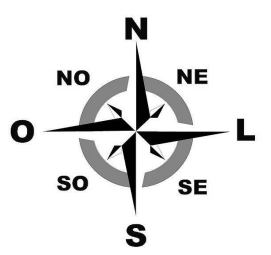

Classificação socioeconômica

Nível socioeconômico 1 (7 setores)

Nível socioeconômico 2 (12 setores)

Nível socioeconômico 3 (19 setores)

Nível socioeconômico 4 (30 setores)

Sem informação

FIGURA 6 - Concentração de casos pelos setores censitários agrupados por níveis socioeconômicos. Fonte: do autor. 
Já analisando todo o período, o nível socioeconômico 3 foi o que apresentou o maior números de casos, seguido pelos extratos 4,2 e 1 . Quando o foco da observação foi a proporção de domicílios com casos de dengue, pôde-se perceber que as classes socioeconômicas 1 e 3 foram as mais acometidas, conforme exposto na Tabela 4.

TABELA 4 - Caracterização dos extratos socioeconômicos quanto à distribuição da dengue pelos domicílios/setores.

\begin{tabular}{lcccc}
\hline $\begin{array}{l}\text { Classificação } \\
\text { socioeconômica }\end{array}$ & $\begin{array}{c}\text { Número de } \\
\text { setores }\end{array}$ & $\begin{array}{c}\text { Número de } \\
\text { domicílios }\end{array}$ & $\begin{array}{c}\text { Casos de dengue } \\
\text { geocodificados }\end{array}$ & $\begin{array}{c}\text { Proporção de domicílios } \\
\text { com casos confirmados }\end{array}$ \\
\hline Nível socioeconômico 1 & 7 & 1498 & 18 & 0,0120 \\
Nível socioeconômico 2 & 12 & 2807 & 30 & 0,0107 \\
Nível socioeconômico 3 & 19 & 4788 & 56 & 0,0117 \\
Nível socioeconômico 4 & 30 & 7949 & 38 & 0,0048 \\
Sem Informação & 02 & 05 & 00 & 0,0000 \\
\hline Total & 70 & 17047 & 142 & 0,0392 \\
\hline
\end{tabular}

Fonte: do autor.

Atentando para a caracterização dos setores de forma individualizada e levando em conta todos os casos de dengue de 2001 a 2010, percebeu-se que os setores censitários que contiveram o maior número de casos foram os de número 08, 02 e 27. Em contrapartida, os setores com maior proporção de domicílios com casos de dengue foram os de número 08,27 e 09. Interessante notar que, contrariando a lógica de que a dengue é preponderante em áreas com alta densidade populacional, os setores que apresentaram maior número de casos e proporção de domicílios não corresponderam às regiões com maior número de residências, como pode ser visto na representação tabular do apêndice I. 


\section{DISCUSSÃO}

$\mathrm{Na}$ análise da evolução temporal da dengue, foi possível detectar taxas de incidência mais elevadas entre os meses de março e maio para a maioria dos anos estudados. Em 2002, período epidêmico, a frequência mais alta de casos aconteceu no mês de abril, seguido pelo mês de maio. Já no ano de 2010, segundo período mais expressivo da série, essa ordem foi inversa, tendo o mês de março o maior número de registros, seguido pelo mês de abril. Essa observação é coerente com o cenário de outros estados e municípios da região Sudeste do Brasil, onde, historicamente, os níveis de infestação do vetor mostram sazonalidade bem demarcada, registrando valores altos perto dos meses mais quentes e reduzidos a níveis próximos de zero, no inverno (SÃO PAULO, 2005).

A maior ocorrência de casos confirmados no sexo feminino seguiu um padrão descrito por Flauzino et al. (2009), Oliveira et al. (2009) e Torres (2005), onde tal grupo é mais afetado devido à característica domiciliar do vetor. Flauzino et al. (2009) argumentam ainda que tal concentração também pode decorrer de um viés de notificação, uma vez que as mulheres tendem a usar os serviços de saúde em maior escala. Assim, acredita-se que a pequena diferença entre os gêneros encontrada nesse estudo $(1,07 \%)$ possa estar relacionada à crescente inserção social e profissional das mulheres.

Já o reconhecimento do nível de instrução da população afetada, que nesse trabalho foi intermediário para a maioria dos indivíduos, tem um papel importante no direcionamento das ações de comunicação em saúde. Se o problema da dengue, sob a ótica dos microdeterminantes, é permeado por aspectos ambientais, socioeconômicos e culturais, fica claro que a educação é um instrumento de enfrentamento indispensável. Por meio dela, pode ser viabilizada a melhor estratégia para redução do agravo na comunidade: o desenvolvimento de hábitos cotidianos de prevenção (SANCHES DE LA GUARDIA, et al., 2003; TORRES, 2006).

A observação das faixas etárias mais atingidas, que, juntas, correspondem à fase adulta, mostra que a dengue esteve presente principalmente na população economicamente ativa, achado semelhante às observações de Gonçalves Neto e Rebelo (2004) e de Flauzino et al. (2009). Esses últimos citam trabalhos que fazem menção a possíveis efeitos negativos do acometimento dessa parcela para a economia local e sugerem que tal concentração pode estar relacionada a um 
possível viés de notificação: a busca de atestados médicos para justificar o absenteísmo.

Agora, se as crianças, adolescentes e idosos, que, como as mulheres, permenecem por mais tempo em casa do que em ambientes de trabalho, não constituíram o maior percentual dos casos, qual o sentido de se investigar o local de residência dos indivíduos infectados? Primeiro porque existem no Município muito mais adultos do que pessoas de outros ciclos de vida, logo, a frequência aumentada nessa faixa etária talvez possa ser atribuída ao maior número de susceptíveis com idade entre 20 e 59 anos. A mesma lógica pode ser aplicada para tentar explicar a predominância de casos de dengue em pessoas da raça branca.

Em segundo lugar, não há como levantar pelos dados da Ficha de Notificação se esses adultos, considerados ativos e/ou produtivos, desenvolviam alguma atividade laboral por ocasião da data dos primeiros sintomas, muito menos precisar o local exato onde foi picado pelo vetor, se em casa, se no trabalho ou no trajeto, etc. Ou seja, o endereço da residência constitui a única referência geográfica disponível no banco de dados do Sinan, que pode ser usada para tentar entender o comportamento espacial desse agravo. E, em terceiro lugar, o conhecimento da localização desse domicílio pode ser útil para a vigilância epidemiológica porque, mesmo que a residência não indique necessariamente o lugar onde ocorreu a infecção ou uma área com alta infestação pelo mosquito Aedes aegypti, a mesma passa a ser um possível local de transmissão da doença devido à presença do reservatório homem.

Nesse sentido, o peridomicílio do indivíduo com dengue poderia ser imaginado, sob a luz do parasitologista russo Evgeny Nikanorovich Pavlovsky, como um "Foco Natural de Doenças". Ao se pensar no homem, estritamente, como elemento de uma paisagem geográfica específica, esse conceito de Pavlovsky poderia ser aplicado, entretanto, sabe-se que o homem é um ser ativo, dinâmico, extremamente complexo e dotado de uma psique que o introduz num mecanismo formador do que o geógrafo francês Maximillien Sorre chamou de "Complexo Patogênico" (FERREIRA, 1991; LEMOS; LIMA, 2002; PAVLOVSKY, 196-).

Acredita-se que essa interação entre o ser humano com o meio ambiente, com os agentes causais e vetores das doenças, observada por Sorre, seja a principal justificativa para a heteroneidade espacial da dengue encontrada em Alfenas. Diversos estudos, como o de Flauzino et al. (2009), demonstraram o 
mesmo padrão de não homogeneidade geográfica da incidência de dengue em estudos locais. Numa revisão sobre o assunto, tal característica foi observada em 15 dos 16 trabalhos com dados secundários analisados (FLAUZINO; SOUZA-SANTOS; OLIVEIRA, 2009). Flauzino, Souza-Santos e Oliveira (2011) destacaram, ainda, a necessidade de trabalhos que abordem a localização espacial desses eventos e a importância dos SIG para a identificação de heterogeneidade espacial da dengue em nível local.

Nesta pesquisa, não foi possível verificar se a dinâmica espacial registrada esteve associada a diferenças ambientais entre os bairros, ou se a explicação estaria na participação de profissionais da Atenção Primária à Saúde em ações de orientação e de controle da dengue na comunidade. O fato é que o maior número de aglomerados de casos ocorreu em áreas descobertas pela Estratégia de Saúde da Família e que houve aparentemente uma tendência de redução de casos confirmados, inversamente proporcional ao incremento gradual dessas Equipes no Município.

Roriz-Cruz et al. (2010) também observaram situação semelhante quando compararam o município de Niterói-RJ, que investiu por 20 anos na Atenção Primária e obteve redução da taxa de infestação domiciliar de Aedes aegypti e diminuição da incidência de dengue, com o Município do Rio de Janeiro-RJ, cuja cobertura de cuidados primários de saúde sempre foi baixíssima e não foi vista, no mesmo período, nenhuma mudança significativa em relação àqueles indicadores da dengue. Entretanto, nem sempre a ampliação quantitativa dos serviços de saúde refletem efetividade e resolutividade dos problemas de saúde coletiva, muito menos em se tratando da dengue.

Um trabalho desenvolvido por Ang, Rohani e Look (2010) na Malásia, por exemplo, sobre o papel dos profissionais da Atenção Primária no controle comunitário dessa arbovirose, mostrou que a maioria dos pacientes (96-98\%) sinalizou não terem recebido orientação alguma dos médicos das unidades de atenção primária sobre as medidas preventivas a serem tomadas. Essa conduta profissional diante de um sintomático de dengue configura-se preocupante, uma vez que grande parte dos usuários havia procurado atendimento logo após o início dos primeiros sintomas. Ou seja, ainda na fase de viremia e, portanto, em tempo de agir a favor da prevenção de infecções secundárias.

Outra possível justificativa para a heterogeneidade espacial na ocorrência da 
dengue identificada no presente trabalho talvez seja a dinâmica de introdução e circulação dos respectivos vírus no Município. Considerando-se a predominância de um tipo de vírus circulante, a não repetição de concentrações de casos nos locais anteriormente acometidos pode estar associada à imunidade natural adquirida pelas pessoas que moram naquelas áreas, em decorrência de infecções passadas. $O$ fato de Alfenas abrigar duas importantes Instituições de Ensino Superior, com elevado e contínuo fluxo de estudantes provenientes de várias regiões do País durante o período letivo, também deve ser considerado. Isso porque é possível que diferentes tipos virais sejam importados durante esse processo migratório e contribua para a transmissão da doença entre os residentes. Infelizmente, de acordo com os registros de dengue analisados, o isolamento do agente não foi realizado. Empregaram-se apenas métodos sorológicos com a demonstração da presença de anticorpos da classe IgM, o que inviabiliza o aprofundamento da discussão nesse sentido.

Já para discorrer sobre a relação entre a concentração de casos de dengue e o contexto socioeconômico, o primeiro ponto de discussão é se os quatro agrupamentos de setores censitários realmente representam regiões socioeconomicamente diferentes. Sobre esse aspecto, a própria análise dos valores médios apresentados na Tabela 3, referentes aos parâmetros socioeconômicos adotados, auxilia nessa distinção. Também, por meio da visualização espacial, pôde-se notar que a divisão censitária em Alfenas se aproxima dos limites dos bairros. Essas características, somadas a observações de campo, permitem constatar que as diferenças historicamente conhecidas quanto ao poder aquisitivo da população, ao padrão de construção das residências e à paisagem geográfica dos bairros, foram coerentes com os extratos socioeconômicos obtidos.

Assumindo, dessa forma, que a classificação socioeconômica realizada se aproxima da realidade, outra questão a ser levantada é a falta de um padrão de distribuição sistemática de casos de dengue pelo território. Se por um lado, a visualização espacial dos domicílios com casos de dengue, de cada ano separadamente, apontou uma localização independe do extrato socioeconômico, ao se considerar o conjunto de dados, a impressão já não foi a mesma. O grupo de nível socioeconômico 3 foi o que apresentou o maior número de casos e, no grupo de melhor nível socioeconômico (1), foi percebida maior proporção de domicílios com casos de dengue.

Entretanto, essa análise frequentista por extrato socioeconômico, que atribui 
uma maior proporção de domicílios com casos dengue ao grupo 1 e sugere uma relação maior entre a ocorrência de dengue e o melhor nível socioeconômico, por exemplo, pode estar enviesada. Para perceber tal distorção, basta verificar que esse nível foi o que apresentou o menor número de casos e a menor proporção de domicílios com pessoas infectadas. Assim, acredita-se que a melhor maneira de analisar o comportamento da dengue pelos grupos seja separadamente, ano a ano e, nesse sentido, os aglomerados de casos não apresentaram um padrão de distribuição constante em nenhum dos 4 níveis socioeconômicos. Em outros trabalhos, como o de Mondini e Chiaravalloti Neto (2007), também não foi possível encontrar associação entre a doença e o contexto socioeconômico na quase totalidade do período estudado. Para os autores, essa relação ainda precisa ser mais bem investigada, podendo variar, inclusive, com a realidade de cada município.

Um dos problemas enfrentados durante a pesquisa, que contribuiu para dificultar a localização das residências e que pode ter interferido nos resultados, foi uma alteração cadastral ocorrida no ano de 2005. Nessa ocasião, algumas ruas e avenidas, principalmente, tiveram seus nomes alterados e a maioria da numeração dos domicílios foi substituída. Essa dificuldade confirma o exposto por Skaba (2009), ao afirmar que nem todo evento de saúde contido em uma base de dados pode ser efetivamente localizado. Para $\circ$ autor, diferenças nas estratégias de georreferenciamento e na capacidade do sistema adotados podem resultar em graus de eficiência variáveis, com maiores ou menores perdas de registros. Contudo, os desafios operacionais que permearam esse estudo não inviabilizaram a execução do trabalho que, além de factível, configurou-se extremamente prazeroso. 


\section{CONSIDERAÇÕES FINAIS}

Assumindo que os dados de dengue obtidos no Sinan, que os dados sócioeconômico/demográficos disponibilizados pelo IBGE e que os dados cartográficos do Município constituem referências válidas para representar a realidade local, observou-se que a doença atingiu, com maior frequência: indivíduos do sexo feminino, adultos, de raça branca e com ensino fundamental completo; nos meses de março, abril e maio; com distribuição espacial bastante heterogênea pelo território. Houve densidade de casos mais elevada nos bairros Aparecida e Centro, aglomerações principalmente nas áreas descobertas pela Estratégia Saúde da Família e em setores censitários de diversos níveis socioeconômicos.

Foram registrados aspectos da dengue referentes à pessoa, ao tempo e ao lugar, que ora se assemelharam às de outros trabalhos publicados, ora apresentaram peculiaridades locais. Dentre os resultados que não distoaram do conhecimento científico, estiveram: o perfil epidemiológico dos casos confirmados, o padrão de sazonalidade da doença no Brasil e a distribuição espacial heterogênea dos aglomerados de casos pelo território. Já dentre as questões que precisam ser mais bem investigadas, estão as hipóteses de que não há associação entre a concentração de casos e os extratos sócioeconômicos, que as características geoepidemiológicas observadas podem estar associadas à dinâmica da circulação viral no Município e que o fato das pessoas residirem em áreas cobertas pela Estratégia Saúde da Família constitui um fator de proteção para a dengue. Esperase que essa discussão possa motivar novos estudos sobre o tema e subsidiar proposições de medidas integrativas/participativas entre a Estratégia Saúde da Família, o Setor de Vigilância Epidemiológica e a comunidade para o controle da dengue no Município. 


\section{REFERÊNCIAS}

ANG, K. T.; ROHANI, I.; LOOK, C. H. Role of primary care providers in dengue prevention and control in the community. Med. J. Malaysia, Singapore, v. 65, n. 1, p. 58-62, mar. 2010.

ARONOFF, S. Geographic information systems: a management perspective. Ottawa: WDL Publications, 1995.

BAILEY, T. C.; GATRELL, A. C. Interactive spatial data analysis. Essex: Longman Scientific \& Technical, 1995. 413 p.

BARCELLOS, C.; BASTOS, F. I. Geoprocessamento, ambiente e saúde: uma união possível? Cad. Saúde Pública, Rio de Janeiro, v. 12, n. 3, p. 389-397, jul./set. 1996.

BARCELLOS, C. et al. Georreferenciamento de dados de saúde na escala submunicipal: algumas experiências no Brasil. Epidemiol. Serv. Saúde, Brasília, v. 17, n. 1, p. 59-70, 2008.

. Identificação de locais com potencial de transmissão de dengue em Porto Alegre através de técnicas de geoprocessamento. Rev. Soc. Bras. Med. Trop., Brasília, v. 38, n. 3, p. 246-250, maio/jun. 2005.

BARCELLOS, C.; SILVA, S. A.; ANDRADE, A. L. S. S. de. Análise de dados em forma de pontos. In: SANTOS, S. M.; SOUZA, W. V. (Org.). Introdução à estatística espacial para a saúde pública. Brasília: Ministério da Saúde, Fundação Oswaldo Cruz, 2007. v. 3. p. 29-59. (Capacitação e atualização em geoprocessamento em saúde).

BRASIL. Ministério da Saúde. DATASUS. Informações de saúde. Brasília, 2009b. Disponível em: <http://tabnet.datasus.gov.br/cgi/tabcgi.exe?ibge/cnv/poptmg.def>. Acesso em: 10 nov. 2009.

BRASIL. Ministério da Saúde. Fundação Nacional de Saúde. Programa Nacional de Controle da Dengue (PNCD). Brasília: Ministério da Saúde, 2002a. 32 p.

BRASIL. Ministério da Saúde. Portaria oㅡ 44, de 3 de janeiro de 2002. Diário Oficial da União, Brasília, DF, 8 jan. 2002b. Seção 1, p. 77. Disponível em:

$<$ http://www.in.gov.br/visualiza/index.jsp?data=08/01/2002\&jornal=1\&pagina=77\&tota IArquivos=104>. Acesso em: 31 jan. 2011.

BRASIL. Ministério da Saúde. Secretaria de Assistência à Saúde. Coordenação de Saúde da Comunidade. Saúde da família: uma estratégia para a reorientação do modelo assistencial. 2. ed. Brasília: Ministério da Saúde,1998. 
BRASIL. Ministério da Saúde. Secretaria de Atenção à Saúde. Departamento de Atenção Básica. Vigilância em saúde: dengue, esquistossomose, hanseníase, malária, tracoma e tuberculose. 2. ed. rev. Brasília: Ministério da Saúde, 2008.197 p.

BRASIL. Ministério da Saúde. Secretaria de Vigilância em Saúde. Departamento de Vigilância Epidemiológica. Guia de vigilância epidemiológica. 6. ed. Brasília: Ministério da Saúde; 2005. 816 p.

Guia de vigilância epidemiológica. 7. ed. Brasília: Ministério da Saúde, 2009a. 816 p.

Sistema de Informação de Agravos de Notificação-Sinan: normas e rotinas. Brasília: Ministério da Saúde, 2006. 80 p.

BRASIL. Ministério da Saúde. Secretaria de Vigilância em Saúde. Secretaria de Gestão do Trabalho e da Educação na Saúde. Dengue: decifra-me ou devoro-te. Brasília: Ministério da Saúde, 2007.

CAIAFFA, W.T. et al. The urban environment from the health perspective: the case of Belo Horizonte, Minas Gerais, Brazil. Cad. Saúde pública, Rio de Janeiro, v. 21, n. 3, p. 958-967, maio/jun. 2005.

CARVALHO, M. S.; CÂMARA, G. Análise espacial de eventos. In: DRUCK, S. et al. (Ed.). Análise espacial de dados geográficos. Brasília: EMBRAPA, 2004. p. 55-76.

CARVALHO, M. S.; PINA, M. F.; SANTOS, S. M. (Org.). Conceitos básicos de sistemas de informação geográfica e cartografia aplicados à saúde. Brasília: Organização Panamericana da Saúde, Ministério da Saúde, 2000.124 p.

CHIARAVALLOTI NETO, F. et al . Controle do dengue em uma área urbana do Brasil: avaliação do impacto do Programa Saúde da Família com relação ao programa tradicional de controle. Cad. Saúde Pública, Rio de Janeiro, v. 22, n. 5, p. 987-997, maio 2006.

COSTA, M. F. L.; BARRETO, S.; GIATTI, L. A situação socioeconômica afeta igualmente a saúde de idosos e adultos mais jovens no Brasil? Um estudo utilizando dados da Pesquisa Nacional por Amostras de Domicílios - PNAD/98. Ciênc. Saúde Coletiva, Rio de Janeiro, v. 7, n. 4, p. 813-824, 2002.

DUARTE, E. C. et al. Epidemiologia das desigualdades em saúde no Brasil: um estudo exploratório. Brasília: Organização Panamericana da Saúde, 2002.

ESPINOZA-GÓMEZ, F. et al. Transmisión interepidémica del dengue en la ciudad de Colima, México. Salud pública Méx., México, v. 45, n. 5, p. 365-370, 2003.

FERREIRA, D. F. Estatística multivariada. Lavras: UFLA, 2008. 662 p. 
FERREIRA, M. U. Epidemiologia e geografia: o complexo patogênico de Max. Sorre. Cad. Saúde Pública, Rio de Janeiro, v. 7, n. 3, p. 301-309, jul./set. 1991.

FLAUZINO, R. F. et al. Heterogeneidade espacial da dengue em estudos locais, Niterói, RJ. Rev. Saúde Pública, São Paulo, v. 43, n. 6, p. 1035-1043, dez. 2009. Disponível em: <http://www.scielosp.org/scielo.php?script=sci_arttext\&pid=S0034$89102009000600016 \&$ Ing=en\&nrm=iso $>$. Acesso em: 28 jul. 2011.

FLAUZINO, R. F.; SOUZA-SANTOS, R.; OLIVEIRA, R. M. Dengue, geoprocessamento e indicadores socioeconômicos e ambientais: um estudo de revisão. Rev. Panam. Salud Pública, Washington, v. 25, n.5, p. 456-461, May. 2009.

. Indicadores socioambientais para vigilância da dengue em nível local.

Saúde Soc., São Paulo, v. 20, n. 1, p. 225-240, jan./mar. 2011. Disponível em: $<$ http://www.scielo.br/scielo.php?script=sci_arttext\&pid=S0104$12902011000100023 \&$ Ing=en\&nrm=iso >. Acesso em: 26 jul. 2011.

FORATTINI, O. P. Ecologia, epidemiologia e sociedade. 2. ed. São Paulo: Artes Médicas, 2004. $720 \mathrm{p}$.

FRANCO, L. J. Epidemiologia descritiva. In: FRANCO, L. J.; PASSOS, A. D.C. (Org.). Fundamentos de epidemiologia. 2. ed. Barueri: Manole, 2011. p. 166-178.

GATRELL, A. C.; BAILEY, T. C. Interactive spatial data analysis in medical geography. Soc. Sci. Med., New York, v. 42, n. 6, p. 843-855, Mar. 1996.

GOOGLE MAPS. 2011. Disponível em: <http://maps.google.com.br/>. Acesso em: 5 maio 2011.

GONÇALVES NETO, V. S.; REBÊLO, J. M. M. Aspectos epidemiológicos do dengue no município de São Luís, Maranhão, Brasil, 1997-2002. Cad. Saúde Pública, Rio de Janeiro, v. 20, n. 5, p. 1427-1431, set./out. 2004.

GONDIM, G. M. M. et al. O território da saúde: a organização do sistema de saúde e a territorialização. Rio de Janeiro: Escola Politécnica de Saúde Joaquim Venâncio, Fundação Oswaldo Cruz. Disponível em:

$<$ http://www.epsjv.fiocruz.br/index.php?Area=ArtCient\&Num=20>. Acesso em: 5 maio 2011.

GORDIS, L. Epidemiologia. 2. ed. Rio de Janeiro: Revinter, 2004. 314 p.

HAIR JR., J. F. et al. Análise multivariada de dados. 5. ed. Porto Alegre: Bookman, 2005. $593 \mathrm{p}$.

IBGE. CENSO 2000. Disponível em: <www.ibge.gov.br/censo/>. Acesso em: 7 maio 2011. 
KAWAMOTO, E. E. Saúde. In: KAWAMOTO, E. E.; SANTOS, M. C. H.; MATTOS, T. M. Enfermagem comunitária. São Paulo: EPU, 1995. p. 11-21.

LEMOS, J. C.; LIMA, S. C. Geografia médica e as doenças infecto-parasitárias.

Caminhos de Geografia, Uberlândia, v. 3, n. 6, p. 74-86, jun. 2002.

MEDRONHO, R. A.; WERNECK, G. L. Técnicas de análise espacial em saúde. In: MEDRONHO, R. A. et al. Epidemiologia. São Paulo: Atheneu, 2005. p. 427-446.

MINAS GERAIS. Secretaria de Estado de Saúde. Linha-Guia de Atenção à Saúde: Dengue. Belo Horizonte: SAS/MG, 2009. 104 p.

MINGOTI, S. A. Análise de dados através de métodos de estatística

multivariada: uma abordagem aplicada. Belo Horizonte: Ed. da UFMG, 2005. 297 p.

MONDINI, A.; CHIARAVALLOTI NETO, F. Variáveis socioeconômicas e a transmissão de dengue. Rev. Saúde Pública, São Paulo, v. 41, n. 6, p. 923-930, dez. 2007.

MONKEN, M., BARCELLOS, C. Vigilância em saúde e território utilizado: possibilidades teóricas e metodológicas. Cad. Saúde Pública, Rio de Janeiro, v. 21, n.3, p. 898-906, maio/jun. 2005.

MORAES, G. H.; DUARTE, E. C. Análise da concordância dos dados de mortalidade por dengue em dois sis temas nacionais de informação em saúde, Brasil, 20002005. Cad. Saúde Pública, Rio de Janeiro, v. 25, n.11, p. 2354-2364, nov. 2009.

NUNES, A. et al. Medindo as desigualdades em saúde no Brasil: uma proposta de monitoramento. Brasília: Organização Pan-Americana de Saúde, Instituto de Pesquisas Econômicas Aplicadas, 2001. 244 p.

OLIVEIRA, E. C. L. et al . Alterações hematológicas em pacientes com dengue. Rev. Soc. Bras. Med. Trop., Brasília, v. 42, n. 6, p. 682-685, dez. 2009. Disponível em: <http://www.scielo.br/pdf/rsbmt/v42n6/14.pdf>. Acesso em: 28 jul. 2011.

OLIVEIRA, E. X. G. et al. Análise de dados espaciais. In: SANTOS, S.; SOUZASANTOS, R. (Org.). Sistemas de informações geográficas e análise espacial na saúde pública. Brasília: Ministério da Saúde, Fundação Oswaldo Cruz, 2007. v. 2. p. 63-80. (Capacitação e Atualização em Geoprocessamento em Saúde).

PASSOS, A. D. C.; RUFFINO-NETO, A. Estudos transversais. In: FRANCO, L. J.; PASSOS, A. D.C. (Org.). Fundamentos de epidemiologia. 2. ed. Barueri: Manole, 2011. p. 242-246.

PAVLOVSKY, E. Natural nidality of transmissible diseases. Translated from the Russian by Yuri Shirokov. Moscow: Peace Publishers, [196-]. 568 p. 
PEREIRA, J. C. R. Análise de dados qualitativos: estratégias metodológicas para as ciências da saúde, humanas e sociais. 3. ed. São Paulo: EDUSP , 2001. 156 p.

PEREIRA, M. G. Epidemiologia teoria e prática. Rio de Janeiro: Guanabara Koogan, 1995. 583 p.

PIMENTA, A. T. M. Geoepidemiologia da co-morbidade AIDS / tuberculose no estado de São Paulo: Brasil: de 1996 a 2005. 2008. 67 f. Dissertação (Mestrado) Faculdade de Medicina de Ribeirão Preto, Universidade de São Paulo, Ribeirão Preto, 2008.

PINA, M. F. Estruturação de dados não-geográficos em ambiente de sistemas de informação geográfica: estudo de caso na área de saúde pública. 1994.

Dissertação (Mestrado) - Instituto Militar de Engenharia, Rio de Janeiro, 1994.

RAMALHO, W. M. Prefácio. In: SANTOS, S.; BARCELLOS, C. (Org.). Abordagens espaciais na saúde pública. Brasília: Ministério da Saúde, Fundação Oswaldo Cruz, 2006. v. 1. p. 6-7. (Capacitação e Atualização em Geoprocessamento em Saúde).

RENCHER, A. C. Methods of multivariate analysis. 2th ed. New York: J. Wiley, 2002. $708 \mathrm{p}$.

REUNIÃO DOS MINISTROS DA SAÚDE DO MERCOSUL E ESTADOS ASSOCIADOS, 17., 2004, Rio de Janeiro. Plano regional de intensificação das ações de controle da Dengue no Mercosul. Brasília: Ministério da Saúde, 2005. $44 \mathrm{p}$.

RODRIGUES JÚNIOR, A. L. Geoepidemiologia da AIDS e das doenças oportunistas transmissíveis na faixa de fronteira brasileira. 2007. $67 \mathrm{f}$. Tese (Livre - Docência) - Faculdade de Medicina de Ribeirão Preto, Universidade de São Paulo, Ribeirão Preto, 2007.

RORIZ-CRUZ, M. et al. Dengue and primary care: a tale of two cities. Bull. World Health Organ., Geneve, v. 88, n. 4, Apr. 2010.

SANCHES DE LA GUARDIA, J. L. et al. Organização e luta contra o Aedes aegypti em uma comunidade. Rev. Cub. Med. Mil., Habana, v. 32, n. 4, dez. 2003.

SANTOS, S.; BARCELLOS, C. (Org.) Abordagens espaciais na saúde pública. Brasília: Ministério da Saúde, Fundação Oswaldo Cruz, 2006.136 p. v. 1. (Capacitação e Atualização em Geoprocessamento em Saúde).

SÃO PAULO (Estado). Coordenadoria de Controle de Doenças; Superintêndencia de Controle de Endemias. Dengue: ações de combate aos vetores. Rev. Saúde Pública, São Paulo, v. 39, n. 6, p. 985-986, dez. 2005. Disponível em: $<$ http://www.scielo.br/scielo.php?script=sci_arttext\&pid=S0034$89102005000600018 \&$ Ing=en\&nrm=iso $>$. Acesso em: 26 jul. 2011. 
SIQUEIRA, J. B. et al. Household survey of dengue infection in Central Brazil: spatial point pattern analysis and risk factors assessment. Am. J. Trop. Med. Hyg., Baltimore, v. 71, n. 5, p. 646-651, Nov. 2004.

SKABA, D. A. Metodologias de geocodificação dos dados da saúde. 2009. 155 f. Tese (Doutorado) - Escola Nacional de Saúde Pública Sergio Arouca, Rio de Janeiro, 2009.

SNOW, J. Sobre a maneira da transmissão da cólera. São Paulo: Hucitec, ABRASCO, 1990. 249 p.

SOUZA, I. C. A.; VIANNA, R. P. T.; MORAES, R. M. Modelagem da incidência do dengue na Paraíba, Brasil, por modelos de defasagem distribuída. Cad. Saúde Pública, Rio de Janeiro, v. 23, n. 11, p. 2623-2630, nov. 2007.

SOUZA, W. V. et al.Tuberculose no Brasil: construção de um sistema de vigilância de base territorial. Rev. Saúde Pública, v. 39, n. 1, p. 82-89, fev. 2005.

SOUZA-SANTOS, R.; CARVALHO, M. S. Análise da distribuição espacial de larvas de Aedes aegypti na Ilha do Governador, Rio de Janeiro, Brasil. Cad. Saúde Pública, Rio de Janeiro, v. 16, n. 1, p. 31-42, jan./mar. 2000. Disponível em: <http://www.scielosp.org/pdf/csp/v16n1/1562.pdf>. Acesso em: 28 jul. 2011.

STATA Data Analysis and Statistical Software. StataCorp LP, 2011. Disponível em: <http://www.stata.com>. Acesso em: 12 abr. 2011.

TAUIL, P. L. Aspectos críticos do controle do dengue no Brasil. Cad. Saúde Pública, Rio de Janeiro, v. 18, n. 3, p. 867-871, maio/jun. 2002a.

Dengue: as prováveis causas de sua re-emergência e disseminação.

Saúde em Foco: informe epidemiológico em saúde coletiva, v. 24, p. 47-53, 2002b.

TEIXEIRA, M. G. et al. Dynamics of dengue virus circulation: a silent epidemic in a complex urban area. Trop. Med. Int. Health, Oxford, v. 7, n. 9, p. 757-762, Sept. 2002.

TERRAVIEW. Versão 3.2.0. São José dos Campos: INPE, 2010. Disponível em: $<$ http://www.dpi.inpe.br/terraview>. Acesso em: 05 out. 2010.

TORRES, E. M. Dengue. Rio de Janeiro: Fiocruz, 2005. 344 p.

. La prevención de la mortalidad por dengue: un espacio y un reto para la atención primaria de salud. Rev. Panam. Salud Publica, Washington, v. 20, n.1, p. 60-74, jul. 2006. Disponível em: <http://www.scielosp.org/pdf/rpsp/v20n1/31727.pdf>. Acesso em: 28 jul. 2011.

TRPIS, M.; HAUSERMANN, W.; CRAIG, G. B. Estimates of population size, dispersal, and longevity of domestic Aedes aegypti (Diptera: Culicidae) by mark- 
release-recapture in the Village of Shauri Moyo in Eastern Kenya. J. Med. Entomol., Honolulu, v. 32, n. 1, p. 27-33, jan.1995.

VASCONCELOS, P. F. C. et al. Epidemia de dengue em Fortaleza, Ceará: inquérito soro-epidemiológico aleatório. Rev. Saúde Pública, São Paulo, v. 32, n. 5, p. 447454, 1998.

VENDRAMINI, S. H. et al. Tuberculosis risks and socio-economic level: a case study of a city in the Brazilian south-east, 1998-2004. Int. J. Tuberc. Lung. Dis, Paris, v. 10, n.11, p. 1231-1235, nov. 2006.

VIEITES, R. G.; FREITAS, I. A. Pavlovsky e Sorre: duas importantes contribuições à geografia médica. Ateliê Geográfico, Goiânia, v. 1, n. 2, p. 187-201, 2007.

WORLD HEALTH ORGANIZATION. Dengue in the Western Pacific Region. Geneva, 2009. Disponível em: <http://www.wpro.who.int/NR/rdonlyres/6F0B3F743067-4B65-AA10-5D4EA99ED87B/0/Countries_areasatriskofdengue.gif >. Acesso em: 12 nov. 2009.

Dengue haemorrhagic fever: diagnosis, treatment, prevention and control. 2nd ed. Geneva: World Health Organization, 1997. 84 p. 


\section{APÊNDICES}

Apêndice I - TABELA 5 - Caracterização dos setores censitários segundo nível socioeconômico, número de domicílios e ocorrência de dengue.

\begin{tabular}{|c|c|c|c|c|}
\hline Código do setor & $\begin{array}{c}\text { Nível } \\
\text { socioeconômico }\end{array}$ & $\begin{array}{l}\text { Casos de dengue } \\
\text { geocodificados }\end{array}$ & $\begin{array}{l}\text { Número de } \\
\text { domicílios }\end{array}$ & $\begin{array}{l}\text { Proporção de } \\
\text { domicílios } \\
\text { com casos }\end{array}$ \\
\hline 310160705000001 & 1 & 06 & 199 & 0,0302 \\
\hline 310160705000002 & 3 & 09 & 290 & 0,0310 \\
\hline 310160705000003 & 4 & 04 & 267 & 0,0150 \\
\hline 310160705000004 & - & 00 & 00 & - \\
\hline 310160705000005 & 3 & 01 & 333 & 0,0030 \\
\hline 310160705000006 & 2 & 03 & 241 & 0,0124 \\
\hline 310160705000007 & 4 & 03 & 297 & 0,0101 \\
\hline 310160705000008 & 3 & 11 & 248 & 0,0444 \\
\hline 310160705000009 & 2 & 07 & 212 & 0,0330 \\
\hline 310160705000010 & 1 & 04 & 178 & 0,0225 \\
\hline 310160705000011 & 3 & 03 & 218 & 0,0138 \\
\hline 310160705000012 & 4 & 01 & 278 & 0,0036 \\
\hline 310160705000013 & 2 & 05 & 254 & 0,0197 \\
\hline 310160705000014 & 2 & 01 & 188 & 0,0053 \\
\hline 310160705000015 & 1 & 03 & 209 & 0,0144 \\
\hline 310160705000016 & 2 & 00 & 259 & 0,0000 \\
\hline 310160705000017 & 3 & 01 & 298 & 0,0034 \\
\hline 310160705000018 & 3 & 01 & 250 & 0,0040 \\
\hline 310160705000019 & 2 & 04 & 214 & 0,0187 \\
\hline 310160705000020 & 1 & 04 & 171 & 0,0234 \\
\hline 310160705000021 & 2 & 01 & 143 & 0,0070 \\
\hline 310160705000022 & 1 & 01 & 257 & 0,0039 \\
\hline 310160705000023 & 3 & 02 & 256 & 0,0078 \\
\hline 310160705000024 & 4 & 02 & 342 & 0,0058 \\
\hline 310160705000025 & 3 & 02 & 285 & 0,0070 \\
\hline 310160705000026 & 4 & 01 & 280 & 0,0036 \\
\hline 310160705000027 & 3 & 09 & 251 & 0,0359 \\
\hline 310160705000028 & 3 & 00 & 245 & 0,0000 \\
\hline 310160705000029 & 4 & 03 & 322 & 0,0093 \\
\hline 310160705000030 & 3 & 02 & 275 & 0,0073 \\
\hline 310160705000031 & 2 & 02 & 210 & 0,0095 \\
\hline 310160705000032 & 2 & 05 & 294 & 0,0170 \\
\hline 310160705000033 & 4 & 00 & 314 & 0,0000 \\
\hline 310160705000034 & 4 & 01 & 268 & 0,0037 \\
\hline 310160705000035 & 4 & 03 & 285 & 0,0105 \\
\hline
\end{tabular}


(Continuação)

\begin{tabular}{|c|c|c|c|c|}
\hline Código do setor & $\begin{array}{c}\text { Nível } \\
\text { socioeconômico }\end{array}$ & $\begin{array}{c}\text { Casos de dengue } \\
\text { geocodificados }\end{array}$ & $\begin{array}{l}\text { Número de } \\
\text { domicílios }\end{array}$ & $\begin{array}{c}\text { Proporção de } \\
\text { domicílios } \\
\text { com casos }\end{array}$ \\
\hline 310160705000036 & 4 & 01 & 296 & 0,0034 \\
\hline 310160705000037 & 1 & 00 & 216 & 0,0000 \\
\hline 310160705000038 & 3 & 01 & 239 & 0,0042 \\
\hline 310160705000039 & 1 & 00 & 268 & 0,0000 \\
\hline 310160705000040 & 4 & 01 & 253 & 0,0040 \\
\hline 310160705000041 & 4 & 00 & 274 & 0,0000 \\
\hline 310160705000042 & 3 & 03 & 120 & 0,0250 \\
\hline 310160705000043 & 4 & 00 & 358 & 0,0000 \\
\hline 310160705000044 & 4 & 00 & 295 & 0,0000 \\
\hline 310160705000045 & 4 & 00 & 268 & 0,0000 \\
\hline 310160705000046 & 3 & 05 & 333 & 0,0150 \\
\hline 310160705000047 & 3 & 02 & 195 & 0,0103 \\
\hline 310160705000048 & 4 & 01 & 275 & 0,0036 \\
\hline 310160705000049 & 4 & 01 & 339 & 0,0029 \\
\hline 310160705000050 & 4 & 01 & 170 & 0,0059 \\
\hline 310160705000051 & 4 & 01 & 256 & 0,0039 \\
\hline 310160705000052 & 3 & 00 & 290 & 0,0000 \\
\hline 310160705000053 & 2 & 01 & 264 & 0,0038 \\
\hline 310160705000054 & 2 & 01 & 297 & 0,0034 \\
\hline 310160705000055 & 3 & 02 & 256 & 0,0078 \\
\hline 310160705000056 & 3 & 01 & 194 & 0,0052 \\
\hline 310160705000057 & 3 & 01 & 212 & 0,0047 \\
\hline 310160705000058 & 4 & 06 & 323 & 0,0186 \\
\hline 310160705000059 & 4 & 04 & 307 & 0,0130 \\
\hline 310160705000060 & 2 & 00 & 231 & 0,0000 \\
\hline 310160705000061 & 4 & 00 & 207 & 0,0000 \\
\hline 310160705000062 & 4 & 00 & 251 & 0,0000 \\
\hline 310160705000063 & 4 & 00 & 281 & 0,0000 \\
\hline 310160705000064 & 4 & 00 & 338 & 0,0000 \\
\hline 310160705000065 & 4 & 01 & 211 & 0,0047 \\
\hline 310160705000066 & 4 & 01 & 171 & 0,0058 \\
\hline 310160705000067 & 4 & 01 & 311 & 0,0032 \\
\hline 310160705000068 & 4 & 01 & 48 & 0,0208 \\
\hline 310160705000069 & 4 & 00 & 64 & 0,0000 \\
\hline 310160705000070 & - & 00 & 05 & 0,0000 \\
\hline
\end{tabular}

Fonte: do autor. 


\section{Apêndice II - Autorização para coleta de dados}
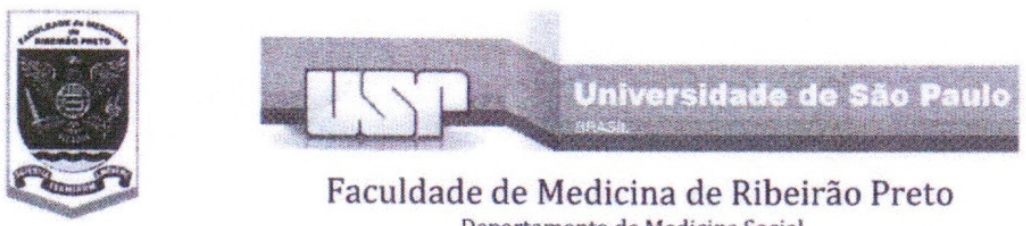

Faculdade de Medicina de Ribeirão Preto Departamento de Medicina Social

\section{SOLICITAÇÃO DE AUTORIZAÇÃO PARA PESQUISA NO MUNICÍPIO}

Alfenas, 17 de novembro de 2010

Assunto: solicitação de autorização para realização de coleta de dados para pesquisa.

\section{Prezada Senhora,}

Vimos, por meio desta, solicitar autorização para realização da coleta de dados para a pesquisa intitulada "Geoepidemiologia da Dengue no Município de Alfenas, MG", a ser desenvolvida pelo Enfermeiro Murilo César do Nascimento sob a orientação do Prof. Dr. Antônio Luiz Rodrigues Júnior, docente do Departamento de Medicina Social da Faculdade de Medicina de Ribeirão Preto - Universidade de São Paulo - USP.

Esclarecemos que esse trabalho resultará numa dissertação de mestrado que tem como objetivo geral caracterizar a incidência de dengue na área urbana do município de Alfenas - MG, no período de 2001 a 2009, segundo características do espaço geográfico, utilizando dados secundários.

Para tanto, as informações serão obtidas por meio de consulta à base de dados do Sistema de Informação de Agravos de Notificação - SINAN, com o auxílio da equipe do Setor de Vigilância Epidemiológica do Município de Alfenas-MG.

Atenciosamente,

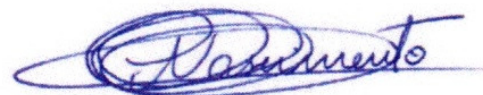

Enfo Murilo César do Nascimento Universidade Federal de Alfenas - Unifal/MG Escola de Enfermagem de Enfermagem Sala R-217 - Tel.: (35) 3299-1380 murilo@unifal-mq.edu.br

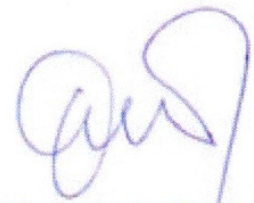

Prof. Dr. Antônio Luiz Rodrigues Júnior

Universidade de São Paulo - USP Faculdade de Medicina de Ribeirão Preto Departamento de Medicina Social Laboratório de Geoepidemiologia Tel.: (16) 6022433. Ramal: 2537
À Sua Senhoria a Senhora

Ludmila Barbosa Bandeira Rodrigues

Secretaria de Saúde da Prefeitura Municipal de Alfenas, MG

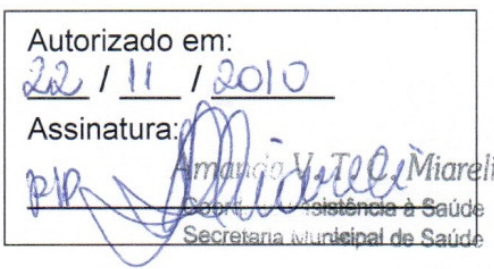




\section{Apêndice III - Comprovante de aprovação pelo Comitê de Ética em Pesquisa}

MINISTÉRIO DA EDUCAÇÃO

Universidade Federal de Alfenas . UNIFAL-MG

Rua Gabriel Monteiro da Silva, 714 . Alfenas/MG. CEP 37130-000

\section{DECLARAÇÃO}

Declaro para todos os fins que o projeto intitulado "GEOEPIDEMIOLOgIA DA DENGUE NO MUNicípIO DE ALFENAS-MG" foi analisado pelo Comitê de Ética em Pesquisa da Unifal-MG, recebendo o parecer APROVADO, conforme registro em Ata da $81^{a}$. Reunião, de 08 de fevereiro de 2011, protocolo $\mathrm{N}^{0}$. $158 / 2010$.

Alfenas, 09 de fevereiro de 2011.

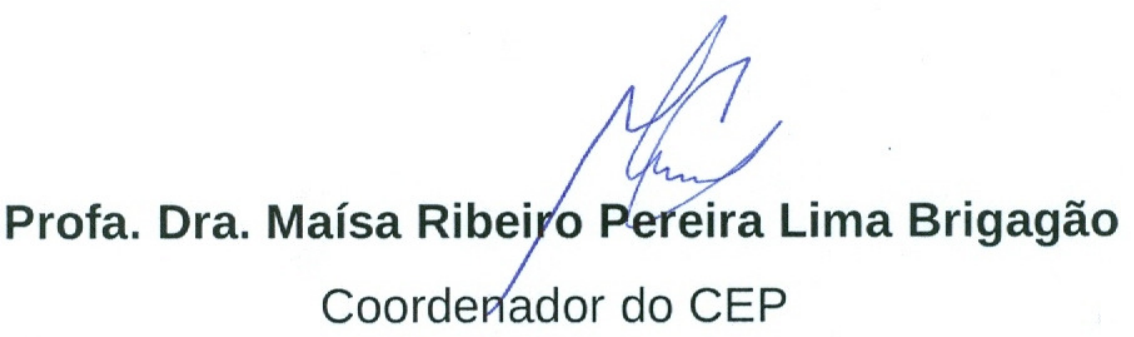




\title{
Anexo I - Relatório de defesa da dissertação
}

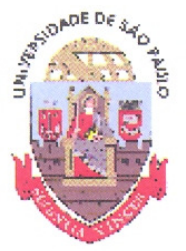

Fanus

\author{
Universidade de São Paulo
}

RELATÓRIO DE DEFESA

Aluno: 17139 - 7113346 - 1 / Página 1 de 1

Relatório de defesa pública de Dissertação do(a) Senhor(a) Murilo César do Nascimento no Programa: Saúde na Comunidade, do(a) Faculdade de Medicina de Ribeirão Preto da Universidade de São Paulo.

Aos 21 dias do mês de outubro de 2011, no(a) FMRP-USP realizou-se a Defesa da Dissertação do(a) Senhor(a) Murilo César do Nascimento, apresentada para a obtenção do título de Mestre intitulada:

"Geoepidemiologia da dengue no município de Alfenas, MG"

Após declarada aberta a sessão, o(a) Sr(a) Presidente passa a palavra ao candidato para exposição e a seguir aos examinadores para as devidas arguições que se desenvolvem nos termos regimentais. Em seguida, a Comissão Julgadora proclama o resultado:

$\begin{array}{llll}\text { Nome dos Participantes da Banca } & \text { Função } & \text { Sigla da CPG } & \text { Resultado } \\ \text { Antonio Luiz Rodrigues Junior } & \text { Presidente } & \text { FMRP - USP } & \text { Aprovado } \\ \text { Amaury Lelis Dal Fabbro } & \text { Titular } & \text { FMRP - USP } & \text { Apuvad } \\ \text { Denismar Alves Nogueira } & \text { Titular } & \text { UNIFAL - Externo } & \text { Apauada }\end{array}$

Resultado Final: Aprovado

Parecer da Comissão Julgadora *

Eu, Jorge Norio Rezende Ikawa , lavrei a presente ata, que assino juntamente com os(as) Senhores(as). Ribeirão Preto, aos 21 dias do mês de outubro de 2011.

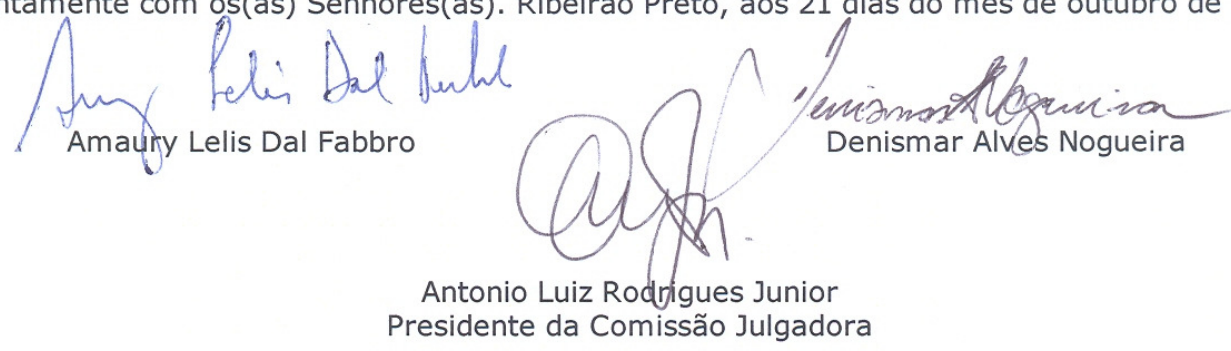

* Obs: Se o candidato for reprovado por algum dos membros, o preenchimento do parecer é obrigatório.

A defesa foi homologada pela Comissão de Pós-Graduação em faz jus ao título de Mestre em Ciências obtido no Programa Saúde na Comunidade.

e, portanto, o(a) aluno(a)

Presidente da Comissão de Pós-Graduação 